\title{
Coordinated Actions of Glyoxalase and Antioxidant Defense Systems in Conferring Abiotic Stress Tolerance in Plants
}

\author{
Mirza Hasanuzzaman 1,2, Kamrun Nahar ${ }^{3,4}$, Md. Shahadat Hossain ${ }^{4}$, Jubayer Al Mahmud ${ }^{4,5}$, \\ Anisur Rahman ${ }^{2,4}$, Masashi Inafuku ${ }^{1}$, Hirosuke Oku ${ }^{1}$ and Masayuki Fujita ${ }^{4, *}$ \\ 1 Molecular Biotechnology Group, Center of Molecular Biosciences, Tropical Biosphere Research Center, \\ University of the Ryukyus, 1 Senbaru, Nishihara, Okinawa 903-0213, Japan; mhzsauag@yahoo.com (M.H.); \\ h098648@eve.u-ryukyu.ac.jp (M.I.); okuhiros@comb.u-ryukyu.ac.jp (H.O.) \\ 2 Department of Agronomy, Faculty of Agriculture, Sher-e-Bangla Agricultural University, \\ Dhaka 1207, Bangladesh; anisur68@yahoo.com \\ 3 Department of Agricultural Botany, Faculty of Agriculture, Sher-e-Bangla Agricultural University, \\ Dhaka 1207, Bangladesh; knahar84@yahoo.com \\ 4 Laboratory of Plant Stress Responses, Faculty of Agriculture, Kagawa University, Miki-cho, Kita-gun, \\ Kagawa 761-0795, Japan; shahadatsau24@gmail.com (M.S.H.); jamahmud_bd@yahoo.com (J.A.M.) \\ 5 Department of Agroforestry and Environmental Science, Faculty of Agriculture, \\ Sher-e-Bangla Agricultural University, Dhaka 1207, Bangladesh \\ * Correspondence: fujita@ag.kagawa-u.ac.jp; Tel.: +81-87-891-3033
}

Academic Editor: Casper G. Schalkwijk

Received: 7 December 2016; Accepted: 10 January 2017; Published: 20 January 2017

\begin{abstract}
Being sessile organisms, plants are frequently exposed to various environmental stresses that cause several physiological disorders and even death. Oxidative stress is one of the common consequences of abiotic stress in plants, which is caused by excess generation of reactive oxygen species (ROS). Sometimes ROS production exceeds the capacity of antioxidant defense systems, which leads to oxidative stress. In line with ROS, plants also produce a high amount of methylglyoxal (MG), which is an $\alpha$-oxoaldehyde compound, highly reactive, cytotoxic, and produced via different enzymatic and non-enzymatic reactions. This MG can impair cells or cell components and can even destroy DNA or cause mutation. Under stress conditions, MG concentration in plants can be increased 2- to 6-fold compared with normal conditions depending on the plant species. However, plants have a system developed to detoxify this MG consisting of two major enzymes: glyoxalase I (Gly I) and glyoxalase II (Gly II), and hence known as the glyoxalase system. Recently, a novel glyoxalase enzyme, named glyoxalase III (Gly III), has been detected in plants, providing a shorter pathway for MG detoxification, which is also a signpost in the research of abiotic stress tolerance. Glutathione (GSH) acts as a co-factor for this system. Therefore, this system not only detoxifies MG but also plays a role in maintaining GSH homeostasis and subsequent ROS detoxification. Upregulation of both Gly I and Gly II as well as their overexpression in plant species showed enhanced tolerance to various abiotic stresses including salinity, drought, metal toxicity, and extreme temperature. In the past few decades, a considerable amount of reports have indicated that both antioxidant defense and glyoxalase systems have strong interactions in conferring abiotic stress tolerance in plants through the detoxification of ROS and MG. In this review, we will focus on the mechanisms of these interactions and the coordinated action of these systems towards stress tolerance.
\end{abstract}

Keywords: abiotic stress; antioxidant defense; glutathione; methylglyoxal; oxidative stress; reactive oxygen species 


\section{Introduction}

Due to global climate change, the frequency and severity of abiotic stresses on plants have been increasing. These stresses include salinity, drought, flooding, high temperature (HT), low temperature (LT), UV-radiation, ozone, and metal toxicity; even their occurrences are often sudden or unpredicted, which causes substantial losses in plant productivity [1,2]. All the abiotic stresses cause physiological and metabolic disorders and adversely affect plant phenological and developmental processes; thus, worldwide abiotic stresses are liable for a yield reduction of more than $50 \%[3,4]$.

One of the major consequences of abiotic stress is oxidative stress [5,6]. Impaired stomatal conductance, disruption of the photosynthetic apparatus or of pigments, malfunctioning of the Calvin cycle and photosystem, inactivation of the enzymes of photosynthesis including RuBisCO, reductions in carboxylation reaction efficiency, electron transport chain (ETC) efficiency, regeneration of $\mathrm{NADP}^{+}$, and increased photorespiration are some of the major reasons for the overproduction of reactive oxygen species (ROS) under abiotic stress [4,7]. Methylglyoxal (MG) is a highly reactive $\alpha, \beta$-dicarbonyl ketoaldehyde, generated as a by-product of several metabolic pathways such as glycolysis, and can be produced from photosynthesis intermediates (glyceraldehyde-3-phosphate) and dihydroxyacetone phosphate. Methylglyoxal production increases 2-6-fold in many plant species under abiotic stress [8]. Reactive oxygen species are highly reactive, and MG is a potent reactive cytotoxin capable of a complete disruption of cellular functions, including the peroxidation of lipids, the oxidation of protein, the oxidation of fatty acids, and the disruption of biomembrane structures and functions $[9,10]$. To scavenge excessively produced ROS, plants possess antioxidant defense system composed of an array of non-enzymatic (ascorbic acid (AsA), glutathione (GSH), phenolic compounds, alkaloids, non-protein amino acids, and $\alpha$-tocopherols) and enzymatic components (superoxide dismutase (SOD), catalase (CAT), ascorbate peroxidase (APX), glutathione reductase (GR), monodehydroascorbate reductase (MDHAR), dehydroascorbate reductase (DHAR), glutathione peroxidase (GPX), and glutathione $S$-transferase (GST) [4,10]. On the other hand, MG is detoxified via the glyoxalase system composed of glyoxalase I (Gly I) and glyoxalase II (Gly II), which catalyze the detoxification of MG to D-lactate using reduced glutathione (GSH) as a cofactor [8]. This is a two-step reaction. The first step, which is catalyzed by Gly I, involves the reaction of MG with GSH, resulting in the formation of hemithioacetal that is then converted to S-D-lactoylglutathione (SLG). In the second step, which is catalyzed by Gly II, GSH is regenerated and D-lactate is formed by the hydrolysis of SLG. At the end of the reaction, GSH is recycled because the availability of GSH is an important factor for detoxifying MG via the glyoxalase system [8].

Enhanced antioxidant defense systems have been reported to improve plant abiotic stress tolerance in different studies. However, the role of the glyoxalase system in relation to abiotic stress tolerance has been studied in a very narrow range [11-25]. Methylglyoxal can catalyze the photoreduction of $\mathrm{O}_{2}$ to $\mathrm{O}_{2}{ }^{\bullet-}$ at photosystem I and increases oxidative stress [26]. Plants' antioxidant defense systems and glyoxalase systems both use GSH-dependent pathways to detoxify ROS and MG, respectively. Therefore, the possibility of an interaction between ROS and MG detoxification systems can be brought under consideration. Some reports have indicated signaling function of ROS and MG in plants [27-29]. The glyoxalase system has been studied widely in animal systems. Glyoxalase I and Gly II have been purified and characterized from a few plant species, but their role is yet to be explored. Moreover, a very recent report explored the presence of Gly III proteins in plants, which performs the function of direct conversion of MG to D-lactate. Identification of this shorter route for MG detoxification is a signpost in the field of glyoxalase system research [25]. Moreover, the biological implication of this pathway under stress has received recent attention. In the present review, we shed light on the coordinated role of antioxidant defense and glyoxalase systems in relation to plant abiotic stress tolerance. 


\section{Oxidative Stress: A Major Consequence in Plants under Abiotic Stress}

Abiotic stress is an unavoidable limiting factor for agriculture and is becoming a significant problem in the modern world. Plants grown under natural conditions are constantly subjected to a variety of abiotic stresses such as salinity, drought, toxic metal/metalloids, HT, LT, waterlogging/ flooding, ozone, and UV radiation. [4]. Atmospheric oxygen as a product of photosynthesis has two great roles for aerobic organisms: firstly, it activates energy production; secondly, it forms ROS [30]. Reactive oxygen species are strong oxidizers and react with a large variety of biological molecules in plant cells. Reactive oxygen species are endlessly produced in plant cells as a result of aerobic metabolism in most intracellular organelles such as chloroplast, mitochondria, and peroxisomes [31]. In each aerobic cell, a dynamic equilibrium was observed between ROS generation and the antioxidant defense system ([4], Figure 1). Abiotic stress increases the ROS generation and disrupts the equilibrium in favor of oxidative reaction and creates oxidative stress [10]. In plant cells, chloroplast is the principal source of ROS generation. Under most stresses, in adequate energy indulgence is occurred in photosynthesis and a successive reduction of molecular oxygen yields ROS including singlet oxygen $\left({ }^{1} \mathrm{O}_{2}\right)$, superoxide anion $\left(\mathrm{O}_{2}{ }^{\bullet-}\right)$, hydrogen peroxide $\left(\mathrm{H}_{2} \mathrm{O}_{2}\right)$, and hydroxyl radical $\left(\mathrm{OH}^{\bullet}\right)[31,32]$. In addition, ROS have also overproduced in non-photosynthetic tissues such as roots, hypocotyls, or coleoptiles under stress, where $\mathrm{O}_{2}{ }^{\bullet-}$ and $\mathrm{H}_{2} \mathrm{O}_{2}$ levels are increased in response to stress followed by a hyper sensitive reaction that leads to cell death. Hence, producing $\mathrm{OH}^{\bullet}$ by cell wall-bound peroxidases is also related with other physiological responses such as the breakdown of cell wall structural polymers [31].

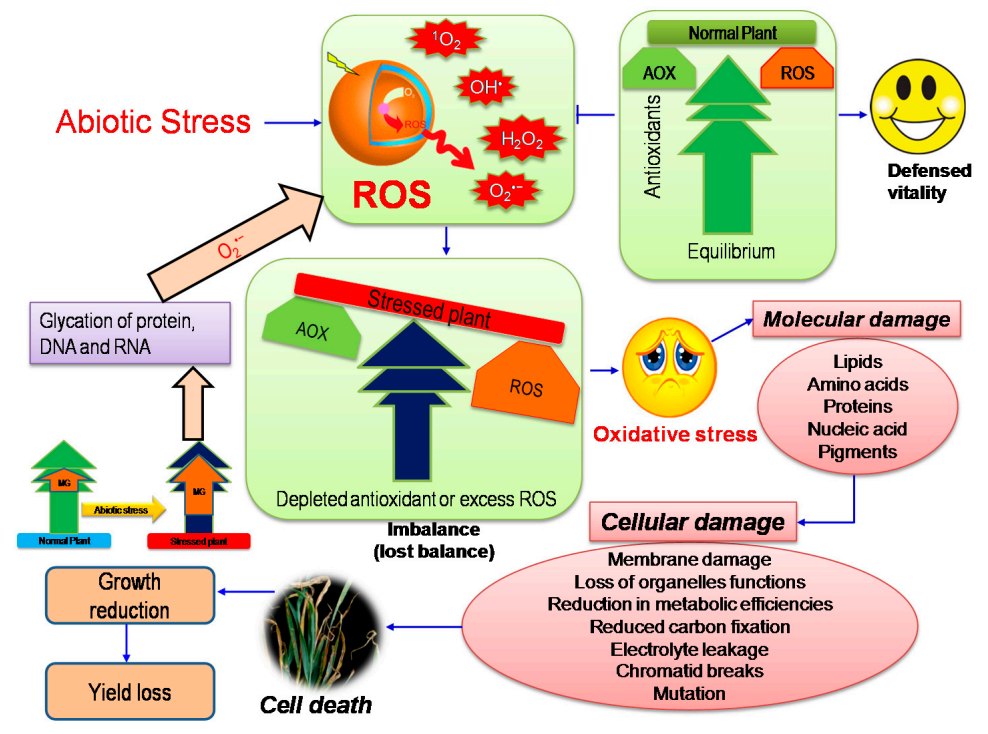

Figure 1. Generation of oxidative stress due to the consequences of abiotic stress (ROS, reactive oxygen species; ${ }^{1} \mathrm{O}_{2}$, singlet oxygen; $\mathrm{O}_{2}{ }^{\bullet-}$, superoxide anion; $\mathrm{H}_{2} \mathrm{O}_{2}$, hydrogen peroxide; $\mathrm{OH}^{\bullet}$, hydroxyl radical; MG, methylglyoxal; AOX, antioxidants).

The mode of ROS production varies among stress types. Under salinity and drought stress, plants want to avoid excess water loss and reduce the stomatal conductance. As a result, internal $\mathrm{CO}_{2}$ concentration decreases, and the reduction of $\mathrm{CO}_{2}$ by the Calvin cycle becomes very slow. This means that salt or drought stress reduces the availability of $\mathrm{CO}_{2}$ and hinders carbon fixation. As a result, chloroplasts of cells become exposed to excessive excited energy and increase the production of different ROS [10]. This excess generation of ROS throughout salt or drought stress results from impaired electron transport procedures in the chloroplasts and mitochondria of plant cells. Reduction of the activity in photosystem II (PS II) results in a disproportion between the production and consumption of electrons, resulting in alterations in quantum yield. These types of modifications in the 
chloroplast photochemistry in the plant leaves of salt- or drought-stressed plants result in a rakishness of excess light energy in the PS II and generate different free radicals such as $\mathrm{O}_{2}{ }^{\bullet-},{ }^{1} \mathrm{O}_{2}, \mathrm{H}_{2} \mathrm{O}_{2}$, and $\mathrm{OH}^{\bullet}$, which are potentially hazardous and create oxidative stress for plants [4]. Under HT stress, RuBisCO is able to generate $\mathrm{H}_{2} \mathrm{O}_{2}$ via oxygenase reactions [33]. On the other hand, under LT/cold stress, the solubility of a gas in plant cells increases. As a result, $\mathrm{O}_{2}$ concentration increases in cells and raises the threat of oxidative damages at LT, which leads to the amplified manufacture of $\mathrm{O}_{2}{ }^{\bullet-}, \mathrm{H}_{2} \mathrm{O}_{2},{ }^{1} \mathrm{O}_{2}$, and $\mathrm{OH}^{\bullet}$ [34]. Reduction of photosynthetic pigment content, inhibition of photochemistry efficiency or the uneven function of PS II, inhibition of biochemical metabolism, or enzymatic activities under LT stress might also be associated with excess ROS generation which is similar to other abiotic stresses $[17,20]$. Under flooding/waterlogging conditions, the photosynthetic ETC becomes over-reduced, causing the generation of several ROS, including $\mathrm{H}_{2} \mathrm{O}_{2}, \mathrm{OH}^{\bullet}$, and ${ }^{1} \mathrm{O}_{2}$ [35]. Normally, heavy metal (HM) stress affects the $\mathrm{H}_{2} \mathrm{O}$ oxidizing system of PS II because $\mathrm{HMs}$ are able to replace $\mathrm{Ca}^{2+}$ and $\mathrm{Mn}^{2+}$ ions in the PS II reaction center; thus, hindering the reaction of PS II results in the uncoupling of the electron transport in the chloroplast. The redox-active $\mathrm{HMs}$ such as $\mathrm{Fe}, \mathrm{Cu}, \mathrm{Cr}, \mathrm{V}$, and $\mathrm{Co}$ enable redox reactions in the cell. They are involved in the formation of $\mathrm{OH}^{\bullet}$ from $\mathrm{H}_{2} \mathrm{O}_{2}$ via Haber-Weiss and Fenton reactions and initiate non-specific lipid peroxidation [36]. However, non-redox-active $\mathrm{HM}$, such as $\mathrm{Cd}^{2+}$ is unable to generate ROS directly through Haber-Weiss reactions. Reactive oxygen species overproduction and the occurrence of oxidative stress in plants are the indirect consequence of cadmium $(\mathrm{Cd})$ toxicity. The mechanisms include the interaction of $\mathrm{Cd}$ with the antioxidant system, the induction of NADPH (nicotinamide adenine dinucleotide phosphate) oxidase, and the disruption of the ETC as well as the metabolism of essential plant nutrients [37-39].

\section{Methylglyoxal: An Unavoidable Foe for Plants}

Methylglyoxal, a cytotoxic compound, is a byproduct of different metabolic activities of the organism. Chloroplast, mitochondrion, and cytosol are potential sources of MG [40,41]. The continuous production of MG carries on as a result of glycolysis [8,40,41]. In normal growth conditions, plant cells contain a small amount of MG; however, under different kinds of abiotic stress, MG production gradually increases [8,42-45]. Therefore, both ROS and MG become toxic for plants under different abiotic stresses because those stresses result in oxidative stress. The main deleterious effect of oxidative stress is the oxidation of cellular components such as lipid peroxidation, protein degradation, and DNA mutations [31]. To be more specific, MG, having ketone and aldehyde functional groups, reacts with deoxyguanosine residues of DNA to produce imidazopurinone MGdG isomers and reacts with guanidino groups of arginine to glycate protein, producing hydroimidazolone N(ס)-(5-hydro-5-methyl-4-imidazolon-2-yl)-ornithine (MG-H1) residues known as advanced glycation end products (AGEs) [46,47]. Subsequently, these AGEs cause protein inactivation and oxidative damage in major cell constituents. Therefore, plants, as well as other living organisms, have the glyoxalase system to protect DNA and protein by converting MG into D-lactate. However, under abiotic stress, MG concentration increases at a rate that is usually higher than the rate of detoxification by the glyoxalase system. A higher accumulation of MG results in the inhibition of germination and cell proliferation and causes the glycation of proteins, the disruption of the antioxidant defense system, and other metabolic dysfunctions [27,28,48,49]. Mankikar and Rangekar [50] found the inhibition of seed germination in a dose-dependent manner with the concentration of MG. Furthermore, MG inhibited the synthesis of protein and nucleic acid. Along with seed germination, root elongation was significantly reduced due to 1 and $10 \mathrm{mM} \mathrm{MG}$ and chlorosis occurred at $10 \mathrm{mM} \mathrm{MG}$ in Arabidopsis [28]. Arabidopsis seed germination was unaffected by MG at concentrations 0.1 and $1.0 \mathrm{mM}$, but seedling growth reduced considerably in both wild-type and D-LDH knock out lines (dldh1-1, d-ldh1-2) in a dose-dependent manner. The severe reduction in D-LDH knock out lines confirms D-lactate dehydrogenase involvement in MG metabolism [51]. Similarly, growth of both tomato and tobacco seedlings were retarded greatly by $1 \mathrm{mM}$ MG [52]. In a recent study, Kaur et al. [40] showed that MG at concentrations of 5, 7.5, 10, 15, and $20 \mathrm{mM}$ caused a reduction in both shoot and root length in a 
dose-dependent manner, and this result is coherent with previous research reports. One reason for this growth reduction in root and shoot may be the inhibition of photosynthesis by MG, as it hampers photosynthesis by inactivating the $\mathrm{CO}_{2}$-photoreduction by $17 \%$ [53]

\section{Methylglyoxal Biosynthesis and Metabolism in Plants}

Methylglyoxal can be produced in living organisms through both enzymatic and non-enzymatic pathways. In enzymatic pathways, three enzymes can generate MG by catalyzing three different metabolites. For example, MG synthase catalyzes the reaction where dihydroxyacetone phosphate (DHAP) is converted to MG and inorganic phosphate, another enzyme called cytochrome P450 can also generate MG from acetone, and MG can similarly be produced from aminoacetone by amine oxidase enzyme. These three enzymes present in mammals, yeasts, and, microbes—surprisingly, but not in plants $[48,54]$. Unlike mammals, yeasts, and microbes, MG is produced in plants mainly by the non-enzymatic route from glyceraldehyde-3-phosphate (GAP), which is an intermediate of glycolysis and photosynthesis, and from DHAP (Figure 2) [48]. The mechanism of non-enzymatic MG formation was explained by Richard [55]. The formation of MG from triosephosphates occurs through $\beta$-elimination of the phosphoryl group from 1,2-enediolate of these trioses, and the rate of this non-enzymatic MG formation is $0.1 \mathrm{mM} \cdot$ day $^{-1}$ [55]. However, it is suspected that other ways of MG formation may be possible in plants, including the metabolism of aminoacetone and acetone $[48,56]$.

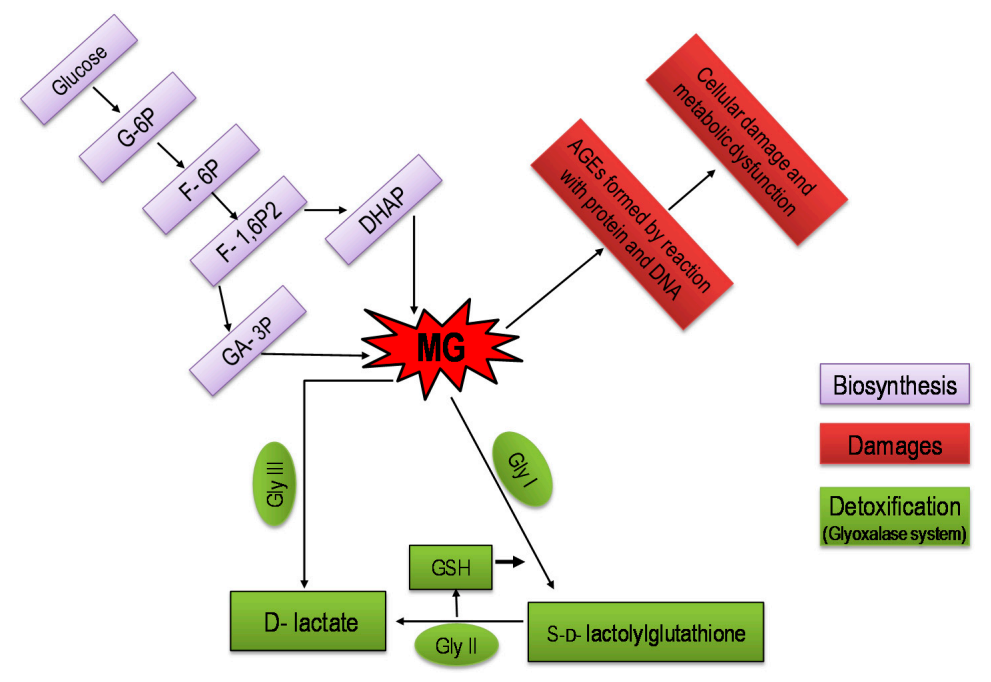

Figure 2. Methylglyoxal biosynthesis, damaging effects, and its detoxification through the glyoxalase system (modified from Kalapos [56] and Kaur et al. [48]) (G-6P, glucose 6-phosphate; F-6P, fructose 6-phosphate; F-1,6P2, fructose 1,6-bisphosphate; GA-3P, glyceraldehyde 3-phosphate; DHAP, dihydroxyacetone-phosphate; GSH, glutathione; Gly I, Glyoxalase I; Gly II, Glyoxalase II; Gly III, Glyoxalase III; AGEs, advanced glycation end products).

Methylglyoxal production is an unavoidable consequence of metabolism, even in normal physiological conditions in living organisms. The major route for MG detoxification is through the glyoxalase system, ubiquitously present in mammals, yeasts, bacteria, and plants $[49,57]$. The glyoxalase enzymes viz. Gly I and Gly II act coordinately to detoxify MG by converting it into a non-toxic product using GSH as a cofactor (Figure 2). However, Ghosh et al. [25] proposed a short route for MG detoxification, where Gly III can convert MG into D-lactate without using GSH. Along with glyoxalase systems, MG can be detoxified via some minor routes. For example, the enzymes involved in oxido-reductions can reduce MG to $\alpha$-oxoaldehyde, as MG contains ketone and aldehyde as functional groups [56]. Therefore, some enzymes such as aldose/aldehyde reductase (ALR) or aldo-keto reductase (AKR) are considered to potentially detoxify MG. Hegedüs et al. [58] 
reported that transgenic tobacco overexpressing ALR reduced malondialdehyde (MDA) content and conferred tolerance to cold and Cd stress. In addition, transgenic tobacco overexpressing OsAKR1, an AKR gene, decreased MG and MDA content under methyl viologen (MV) and HT [59]. Though these studies suggest the role of ALRs and AKRs in the reduction of MG and MG-like aldehyde under stress, the mechanism of MG detoxification through minor routes are still unclear [60].

\section{Glyoxalase System: The Eliminator of Methylglyoxal in Plants}

The MG detoxifying glyoxalase pathway was first reported by two independent groups $[61,62]$ in 1913. The existence of the glyoxalase system was reported in plants in the last decade of the previous century $[63,64]$, which is located in cytosol and other organelles of chloroplast and mitochondria $[43,46]$. Two enzymes, Gly I and Gly II, and GSH act coordinately to eliminate MG ([65]; Figure 2). Due to the involvement of GSH, this MG elimination pathway is also known as a GSH-dependent glyoxalase pathway [48]. However, in the first step of the glyoxalase system, MG produces hemithioacetal via spontaneous reaction with GSH. Hemithioacetal is converted to SLG via 1,2-hydrogen transfer, which is catalyzed by the Gly I enzyme. In the second step, Gly II enzyme converts SLG to D-lactate by hydrolysis, which later confirms the regeneration of GSH [48,65]. Therefore, overexpression or higher activity of glyoxalase enzymes eliminate MG toxicity and confer stress tolerance [48]. Many reports have shown increased or overexpressed Gly I or Gly II as well as both reduced endogenous MG levels and conferred stress tolerance. Overexpression of the Gly I gene in transgenic tobacco showed better stress tolerance than the normal plant to MG and high salinity [66]. Under salt stress, transgenic rice has also shown better tolerance to high MG levels by overexpression of the Gly II gene [67]. Overexpression of both the Gly I and Gly II genes showed better stress tolerance in transgenic tobacco [68]. Increased activities of Gly I and Gly II also confer stress tolerance in rice and mung bean by reducing MG levels under abiotic stress conditions [21,69-73]. Recently, a GSH-independent glyoxalase enzyme named Gly III has been detected in plants that is capable of MG detoxification in a single step. In this step, MG converted to D-lactate by the Gly III enzyme without formation of SLG and/or involving GSH or any other cofactor [25].

\section{Coordinated Actions of Glyoxalase and Antioxidant Defense System in Mitigating Oxidative Stress in Plants}

It is evident that MG production increased under abiotic stress, which plays a role in the over-formation of ROS generation. Under stress, MG increases ROS formation in plant cells directly due to the presence of MG. On the other hand, MG increases ROS formation in plant cells indirectly through the formation of advanced glycation end product (AGEs). Consequently, MG causes a higher formation of ROS, which plays a vital role in inducing oxidative stress [43,74,75]. As a result, elimination of MG can inhibit MG-induced ROS production. On the other hand, production of ROS is unavoidable, and plants are well equipped by their antioxidant defense system to detoxify overproduced ROS. Under environmental stress, ROS production has been shown to increase and is readily scavenged by the plant antioxidant defense system that directly mitigates oxidative stress [10]. There are several enzymatic and non-enzymatic antioxidants that lead to antioxidant defense and defend against oxidative stress [4] (Figure 3). In such cases, GSH plays a central role because it is used in the glyoxalase system by Gly I, which is again regenerated by the action of Gly II (Figure 3). As both antioxidant and glyoxalase systems are involved in ROS detoxification, the coordination of these systems can mitigate oxidative stress by reducing ROS production (Figure 3). Many studies showed the coordinated actions of antioxidant defense and glyoxalase systems in mitigating oxidative stress by detoxifying both ROS and MG, respectively. Exogenously applied phytoprotectants confer environmental stress tolerance by the coordinated action of the upregulated antioxidant defense and the glyoxalase systems in Triticum aestivum [13,16], Brassica napus [11,76], Oryza sativa [77-81], and Vigna radiata seedlings under abiotic stresses. These are discussed in the following sections. 


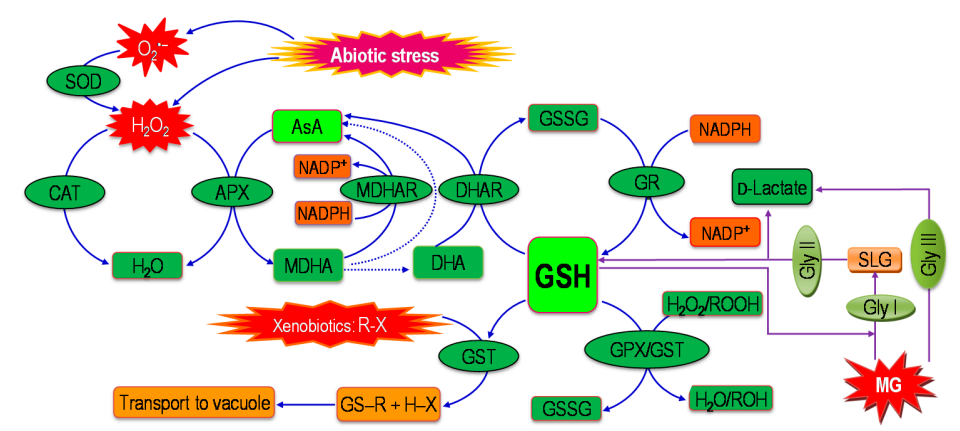

Figure 3. Coordinated actions of antioxidant defense and glyoxalase systems in eliminating the toxic ROS and MG under abiotic stress. Dotted lines denote non-enzymatic conversions. $\mathrm{R}$ may be an aliphatic, aromatic, or heterocyclic group; $\mathrm{X}$ may be a sulfate, nitrite, or halide group. (Ascorbic acid, AsA; glutathione, GSH; glutathione dissulfide, GSSG; superoxide dismutase, SOD; catalase, CAT; ascorbate peroxidase, APX; MDHA, monodehydroascorbate; monodehydroascorbate reductase, MDHAR; DHA, dehydroascorbate; dehydroascorbate reductase, DHAR; glutathione reductase, GR; glutathione peroxidase, GPX; glutathione $S$-transferase, GST; NADP, nicotinamide adenine dinucleotide phosphate; Gly I, glyoxalase I; Gly II, glyoxalase II; SLG, S-D-lactoylglutathione). (Adapted from Hasanuzzaman et al. [4].) Solid arrows indicate enzymatic reactions while dotted arrows indicate non-enzymatic reactions.

\section{Regulation of the Glyoxalase System and the Antioxidant Defense System in Plants under Abiotic Stress}

\subsection{Salinity}

Under abiotic stress, the production of MG content increased drastically due to a higher rate of glycolysis, amino acid, and acetone metabolism, or other biochemical processes. Due to a higher production of $M G$, the glyoxalase system is regulated under various environmental stresses, including salinity $[8,42,67,82]$. However, many reports have shown that MG levels increase and glyoxalase enzymes upregulate or downregulate depending on salinity level, stress duration, and/or plant species (Table 1). The exposure of $300 \mathrm{mM} \mathrm{NaCl}$ has been shown to increase the MG level and Gly I activity after $24 \mathrm{~h}$ in Cucurbita maxima [57]. Hossain and Fujita [83] reported that salt stress caused ROS-induced oxidative stress in $V$. radiata seedlings with a concomitant decrease in the redox state of GSH. They also reported that exogenously applied proline (Pro) and glycinebetaine (GB) alleviated salt-induced oxidative stress by involving ROS and MG detoxification. Hossain et al. [84] also noted that the exposure of $150 \mathrm{mM} \mathrm{NaCl}$ regulated antioxidant defense and glyoxalase systems (increased Gly I and Gly II activity) in B. campestris, which is further upregulated by $5 \mathrm{~h}$ of heat shock and alleviated salt-induced damage through ROS and MG detoxification. On the other hand, Hasanuzzaman et al. $[11,76,77]$ showed that increased salinity decreased Gly I and Gly II activity along with increased ROS production in Triticum aestivum, B. napus, and O. sativa seedlings (Table 1). They also showed that the exogenous application of phytoprotectants (nitric oxide, salicylic acid, Pro, and GB) increased ROS detoxification by upregulating antioxidant defense and glyoxalase (further stimulating Gly I and Gly II activities) systems and mitigating salt-induced oxidative stress. Mostofa et al. [78] reported that glyoxalase enzyme (Gly I and Gly II) activity and the level of oxidative stress increased with increasing salinity levels in rice seedlings (Table 1). Later, Mostofa et al. [79] showed that exposure to $150 \mathrm{mM} \mathrm{NaCl}$ disrupted glyoxalase (increased MG content and decreased Gly I activity) and antioxidant defense (increased ROS production) systems in O. sativa seedlings. Recently, Rahman et al. [80,81] showed that the exposure of 150 and $200 \mathrm{mM} \mathrm{NaCl}$ increased ROS production by disrupting ion homeostasis and antioxidant defense and glyoxalase (increased MG production) systems. They also noted that the exogenous application of $\mathrm{Ca}$ and Mn reduced ROS-induced oxidative damage by the coordinated action of nutrient homeostasis and antioxidant defense and glyoxalase systems (Table 1). 
Table 1. Regulation of the glyoxalase system and associated antioxidant defense system in plants under salt stress.

\begin{tabular}{|c|c|c|c|c|c|}
\hline $\begin{array}{c}\text { Plant } \\
\text { Species }\end{array}$ & $\begin{array}{l}\text { Stress (Dose } \\
\text { and Duration) }\end{array}$ & Changes in Glyoxalase and Antioxidant Defense Systems & Protectants & $\begin{array}{l}\text { Changes in Glyoxalase and Antioxidant Defense Systems } \\
\text { after Protection }\end{array}$ & Reference \\
\hline V. radiata & $\begin{array}{l}300 \mathrm{mM} \mathrm{NaCl} \\
24 \text { and } 48 \mathrm{~h}\end{array}$ & $\begin{array}{l}\text { - } \quad \text { Increased Gly I activity } \\
\text { - } \quad \text { Gly II activity increased to 1.5- and 1.2-fold after } 24 \text { and } \\
\text { - } \quad \text { MDA respectively } \\
\text { - } \quad \text { GSH and } \mathrm{H}_{2} \mathrm{O}_{2} \text { content increased } \\
\text { - } \quad \text { Increased GPX contents increased } \\
\end{array}$ & $\begin{array}{l}15 \text { mM Pro, } \\
15 \text { mM GB }\end{array}$ & $\begin{array}{ll}\text { - } & \text { Further increase in Gly I activity by } 12 \% \text { and } 17 \% \text { after } 24 \\
\text { - } & \text { and } 48 \mathrm{~h} \text {, respectively } \\
\text { - } & \text { Increased GSH content } \\
\text { - } & \text { Increased GPX, GST and GR activities } \\
\text { - } & \text { Decreased MDA and } \mathrm{H}_{2} \mathrm{O}_{2} \text { contents }\end{array}$ & [83] \\
\hline B. campestris & $\begin{array}{c}150 \mathrm{mM} \mathrm{NaCl} \\
48 \mathrm{~h}\end{array}$ & $\begin{array}{ll}\text { - } & \text { Increased Gly I activity } \\
\text { - } & \text { Gly II activity decreased by } 18 \% \\
\text { - } & \text { Increased AsA and } \mathrm{GSH} \text { contents } \\
\text { - } & \text { Increased MDA and } \mathrm{H}_{2} \mathrm{O}_{2} \text { contents } \\
\text { - } & \text { Upregulated APX, MDHAR, DHAR and GR activities }\end{array}$ & $\begin{array}{l}\text { Heat shock } \\
\left(42^{\circ} \mathrm{C}\right), 5 \mathrm{~h}\end{array}$ & $\begin{array}{l}\text { - } \quad \text { Further increase in Gly I activity by } 19 \% \\
\text { - } \quad \text { Furreased Gly II activity by } 22 \% \\
\text { APX, DHAR, GR and GPX }\end{array}$ & [84] \\
\hline B. napus & $\begin{array}{l}100 \text { and } 200 \mathrm{mM} \\
\mathrm{NaCl}, 48 \mathrm{~h}\end{array}$ & $\begin{array}{ll}\text { - } & \text { Decreased Gly I activity by } 21 \% \text { and } 33 \% \text { with } 100 \text { and } \\
& 200 \mathrm{mM} \mathrm{NaCl} \text {, respectively } \\
\text { - } & \text { Decreased Gly II activity by } 30 \% \text { and } 37 \% \text { with } 100 \text { and } \\
& 200 \mathrm{mM} \text { NaCl, respectively } \\
\text { - } & \text { Decreased AsA content } \\
\text { - } & \text { Increased GSH and GSSG contents } \\
\text { - } & \text { Increased production of } \mathrm{H}_{2} \mathrm{O}_{2} \text { and lipid peroxidation } \\
\text { - } & \text { Increased APX and GR activities } \\
\text { - } & \text { Decreased MDHAR, DHAR and CAT activities } \\
\end{array}$ & $100 \mu \mathrm{M} \mathrm{SA}$ & $\begin{array}{l}\text { - } \quad \text { Increased Gly I activity } \\
\text { - } \text { Gly II activity increased further by } 31 \% \text { and } 37 \% \text { with } 100 \\
\text { - } \quad \text { Decreased } 200 \mathrm{mM} \text { NaCl, respectively } \\
\text { - } \quad \text { Further increase in ASA and GSH contents } \\
\text { - } \quad \text { Upregulated APX, MDHAR, DHAR, GR and } \\
\text { CAT activities }\end{array}$ & [76] \\
\hline T. aestivum & $\begin{array}{c}150 \text { and } 300 \mathrm{mM} \\
\mathrm{NaCl}, 4 \text { days }\end{array}$ & $\begin{array}{ll}\text { - } & \text { Gly I activity decreased by } 12 \% \text { and } 26 \% \text { with } 150 \text { and } \\
& 300 \mathrm{mM} \mathrm{NaCl} \text {, respectively } \\
\text { - } & \text { Decreased Gly II activity } \\
\text { - } & \text { Decreased AsA content } \\
\text { - } & \text { Increased GSH and GSSG contents } \\
\text { - } \quad \text { Increased ROS production and lipid peroxidation with } \\
\text { increasing salinity }\end{array}$ & $\begin{array}{l}1 \mathrm{mM} \text { sodium } \\
\text { nitroprusside } \\
(\mathrm{SNP}), 24 \mathrm{~h} \\
\text { pretreatment }\end{array}$ & $\begin{array}{l}\text { - } \text { Gly I activity further increased by } 26 \% \text { and } 25 \% \text { with } 150 \\
\text { - } \quad \text { and } 300 \mathrm{mM} \mathrm{NaCl} \text {, respectively } \\
\text { - } \quad \text { Decreased Gly II activity } \\
\text { - Increased ASA and GSH contents } \\
\text { - Increased MDHAR, DHAR and GR activities }\end{array}$ & [12] \\
\hline O. sativa & $\begin{array}{c}150 \text { and } 300 \mathrm{mM} \\
\mathrm{NaCl}\end{array}$ & $\begin{array}{l}\text { - } \quad \text { Gly I activity decreased in sensitive cultivar and increased } \\
\text { in tolerant cultivar } \\
\text { - } \quad \text { Decreased chlorophyll (chl) content } \\
\text { - } \quad \text { Increased } \mathrm{H}_{2} \mathrm{O}_{2} \text { production and lipid peroxidation } \\
\text { - } \quad \text { Increased Pro content }\end{array}$ & $\begin{array}{c}5 \mathrm{mM} \text { Pro and } \\
5 \mathrm{mM} \mathrm{GB}\end{array}$ & $\begin{array}{l}\text { - Increased Gly I and Gly II activities } \\
\text { - } \quad \text { Increased chl content } \\
\text { - } \quad \text { Uecreased ROS production and lipid peroxidation } \\
\quad \text { preguled nonzymatic and enzymatic antioxidants }\end{array}$ & [77] \\
\hline
\end{tabular}


Table 1. Cont.

\begin{tabular}{|c|c|c|c|c|c|}
\hline $\begin{array}{c}\text { Plant } \\
\text { Species }\end{array}$ & $\begin{array}{c}\text { Stress (Dose } \\
\text { and Duration) }\end{array}$ & Changes in Glyoxalase and Antioxidant Defense Systems & Protectants & $\begin{array}{l}\text { Changes in Glyoxalase and Antioxidant } \\
\text { Defense Systems after Protection }\end{array}$ & Reference \\
\hline O. sativa & $\begin{array}{l}150 \text { and } 250 \mathrm{mM} \\
\mathrm{NaCl}, 72 \mathrm{~h}\end{array}$ & $\begin{array}{ll}\text { - } & \text { Increased Gly I and Gly II activities with increasing } \\
& \text { salt stress } \\
\text { - } & \text { Increased ROS production and MDA content } \\
\text { - } & \text { Decreased AsA content and increased GSH content } \\
\text { - } & \text { Increased SOD, GPX, APX, DHAR and GR activities } \\
\text { - } & \text { Decreased CAT and GST activities } \\
\end{array}$ & $\begin{array}{c}10 \mathrm{mM} \\
\text { Trehalose (Tre) }\end{array}$ & $\begin{array}{ll}\text { - } & \text { Further increase in Gly I activity } \\
\text { - } & \text { Further increase in Gly II activity } \\
\text { - } & \text { Decreased SOD, CAT, MDHAR, DHAR and GR activities } \\
\text { lipoxygenase (LOX) activity and MDA content }\end{array}$ & [85] \\
\hline O. sativa & $\begin{array}{l}150 \mathrm{mM} \mathrm{NaCl} \\
4 \text { days }\end{array}$ & $\begin{array}{ll}\text { - } & \text { Increased MG content by } 58 \% \\
\text { - } & \text { Gly I activity increased by } 12 \% \\
\text { - } & \text { Decreased chl content } \\
\text { - } & \text { Increased ROS production } \\
\text { - } & \text { Increased lipid peroxidation } \\
\end{array}$ & $50 \mu \mathrm{M} \mathrm{H}_{2} \mathrm{~S}$ & $\begin{array}{ll}\text { - } & \text { Decreased MG content } \\
\text { - } & \text { Increased Gly I and Gly II activities } \\
\text { - } & \text { Increased chl content } \\
\text { - } & \text { Decreased Pro content } \\
\text { - } & \text { Decreased ROS production and lipid peroxidation } \\
\end{array}$ & [78] \\
\hline O. sativa & $\begin{array}{l}200 \mathrm{mM} \mathrm{NaCl} \\
3 \text { days }\end{array}$ & $\begin{array}{ll}\text { - } & \text { Increased MG content by } 44 \% \\
\text { - } & \text { Increased Gly I and Gly II activities by } 21 \% \text { and } \\
& 29 \% \text {, respectively } \\
\text { - } & \text { Increased } \mathrm{ROS}\left(\mathrm{H}_{2} \mathrm{O}_{2}, \mathrm{O}_{2} \bullet-\right. \\
& \text { peroxidation (MDA production and lipid } \\
\text { - } & \text { Decreased AsA content and increased GSH content }\end{array}$ & $2 \mathrm{mM} \mathrm{CaCl}_{2}$ & $\begin{array}{l}\text { - } \quad \text { Decreased MG content } \\
\text { - } 20 \% \text { respectively } \\
\text { - Increased ROS and MG detoxification }\end{array}$ & [80] \\
\hline O. sativa & $\begin{array}{l}150 \mathrm{mM} \mathrm{NaCl} \\
3 \text { and } 6 \text { days }\end{array}$ & $\begin{array}{ll}\text { - } & \text { Increased MG content with increasing stress duration } \\
\text { - } & \text { Increased Gly I and Gly II activities with increasing } \\
\text { - } & \text { Incress duration } \\
\text { - } & \text { Increased ROS production } \\
\text { - } & \text { Decreased AsA content } \\
& \text { GSSG contents }\end{array}$ & $\begin{array}{l}0.5 \mathrm{mM} \\
\mathrm{MnSO}_{4}\end{array}$ & $\begin{array}{l}\text { - } \quad \text { Decreased MG content } \\
\text { - } \quad \text { Increased ROS and MG detoxification } \\
\text { - } \quad \text { Increased chl content } \\
\text { - } \\
\quad \text { oscreased osmotic stress (decreased Pro content, } \\
\text { osmotial) }\end{array}$ & [81] \\
\hline
\end{tabular}




\subsection{Drought}

Drought stress indicates a deficit of water such that substantial damage to plant developmental processes results. Disrupted or reduced enzyme activities, loss of cell water content, or turgor are the primary effects of drought stress, causing reductions in cell division and expansion as well as in plant growth $[22,86]$. Like other stresses, drought also overproduced MG, interrupting the glyoxalase system as documented in several plant studies (Table 2) [14,17-24].

Drought stress augmented the activity of Gly I but diminished the activity of Gly II in rapeseed seedlings. Via drought treatment, increases in GSH and GSSG content and decreases in GSH/GSSG ratios have been demonstrated. The level of AsA has been shown to increase only under mild stress (induced by $10 \%$ PEG, compared to severe drought stress induced by $20 \%$ ). The MDHAR and GR activities have increased only under mild stress (10\% PEG). The activities of DHAR, GST, and GPX have increased, but CAT activity has decreased at both levels of stress. Disruption of antioxidant defense and glyoxalase system via drought treatments was shown to result in a sharp increase in $\mathrm{H}_{2} \mathrm{O}_{2}$ and lipid peroxidation, which are indicators of oxidative stress [14]. Mung bean (V. radiata L. cv. Binamoog-1) seedlings were subjected to drought stress (induced by $25 \%$ polyethylene glycol 6000, PEG) for 24 and $48 \mathrm{~h}$. Drought stress increased the level of MG content with a concomitant increase in GSH content and activities of Gly I and Gly II. Drought-affected seedlings faced oxidative stress, which is clear from the high increase in $\mathrm{H}_{2} \mathrm{O}_{2}$ and $\mathrm{O}_{2}{ }^{\bullet-}$ content and their spots in the leaves (detected by histochemical staining), which was due to a disrupted antioxidant defense system (decreased AsA content, increased GSH and GSSG contents, decreased GSH/GSSG ratio, and decreased MDHAR, DHAR, and CAT activities). Some other physiological attributes of mung bean seedlings such as leaf chl content, leaf succulence, and relative water content (RWC) have been shown to decrease, and proline (Pro) content has been shown to increase due to drought [19]. Oryza sativa L. cv. IR64 overexpressed OsDJ-1C, which enhanced MG detoxification and the formation of D-lactate. In this conversion of D-lactate from MG, the activity of the Gly III enzyme was involved in demonstrating the existence of functional GLY III as a shorter route for MG detoxification [25]. Osmotic stress also upregulated the Gly I activity in tomato [87]. MG increased significantly in tobacco plants in response to drought [88]. Tomato (encoding gene for Gly I) plants showed enhanced Gly I activity 2-3-fold in all cell types of roots, stems, and leaves, especially in phloem sieve elements, under water deficit stress [87]. The Glyoxalase I gene was cloned and characterized from B. juncea. The expression of Gly I was upregulated in response to water stress. The level of transcript, protein, and specific activity of Gly I was markedly enhanced under water stress [66]. In another study, V. radiata seedlings were subjected to drought stress (induced by $5 \%$ PEG, $48 \mathrm{~h}$ ), their performance was compared with control seedlings. Exogenous drought treatment caused endogenous drought stress, which is reflected in a decreased leaf RWC, water saturation deficit, water retention capacity, and increased Pro. According to the investigation, drought-affected seedlings faced oxidative damage, which was exhibited by a breakdown of chl and increased lipid peroxidation. The reason behind this was that overproduction of $\mathrm{ROS}$ including $\mathrm{H}_{2} \mathrm{O}_{2}$ and $\mathrm{O}_{2}{ }^{\bullet-}$, an increase in LOX activity, a disruption of the antioxidant defense system (decreased content of AsA, AsA/DHA and GSH/GSSG ratios, and activities of CAT, APX, MDHAR, DHAR, and GR) and obviously the overproduction of toxic $M G$, which is not only directly responsible for oxidative damage but also responsible for ROS production that causes oxidative damage. The increase in toxic MG was due to the modulation of glyoxalase system components including Gly I and Gly II activities, the content of GSH and GSSG, and the ratio of GSH/GSSG [22]. Aldose/aldehyde reductase is cytosolic NADPH-dependent oxidoreductase, catalyzing the reduction of a variety of aldehydes and carbonyls. According to Hideg et al. [89], under drought stress, transgenic tobacco (compared to control) showed higher ALR activity, which was highly correlated to reduced $\mathrm{H}_{2} \mathrm{O}_{2}$ and $\mathrm{OH}^{\bullet}$ radical production, as well as the production of thiobarbituric acid reactive species (lipid peroxidation products), all of which indicate a reduction in oxidative damage. Transformed plants were more tolerant and exhibited a reduced loss of photosynthetic function. In a recent study, higher ALR activity might have roles in reducing MG content, which further decreased ROS production, but this needs further 
investigation [89]. A similar report was observed in another previous study [90]. The recombinant alfalfa had been developed for ALR. A reduction in the generation of lipid peroxidation-derived reactive aldehydes in these transformed plants has been documented over a long period of water deficiency, which also showed improved recovery after rehydration [90].

\subsection{Toxic Metals/Metalloids}

Toxic metal stress drastically amplifies the MG level of plant cells and creates oxidative stress $[21,23,69,91,92]$. Many recent studies have confirmed that, under metal stress, the level of MG increases without a proper detoxification process of the glyoxalase system (Table 3). Sometimes, the individual enzymes of the glyoxalase system, Gly I and Gly II, or both, increase in the primary stage of metal stress. However, in most cases, with an increase in the duration of stress, the activity of glyoxalase enzymes decreases. Therefore, the increase or decrease of glyoxalase enzymes depends on stress intensity and duration. However, many researchers have used different kinds of plant protectants against metal stresses and found that these types of protectants upregulated the enzymes of the glyoxalase system and defended toxic MG or MG-induced oxidative stress. Hossain et al. [57] observed that $1 \mathrm{mM} \mathrm{CdCl} 2$ stress for $24 \mathrm{~h}$ in Cucurbita maxima increased MG and upregulated the activity of the Gly I enzyme. This upregulation of Gly I activity may be due to a short duration of stress. However, in V. radiata, $1 \mathrm{mM} \mathrm{CdCl}_{2}$ stress for $48 \mathrm{~h}$, slightly increased Gly I activity but decreased Gly II activity as well as increased accumulation of MG [93]. However, significant reduction of this MG enhancement was observed after using exogenous protectant ( $5 \mathrm{mM}$ Pro or $5 \mathrm{mM} \mathrm{GB}$ ). Hasanuzzaman et al. [94] carried out an experiment with rapeseed plant under 0.5 and $1.0 \mathrm{mM} \mathrm{CdCl}_{2}$ stress and demonstrated that Gly I activity significantly decreased by $18 \%$ and $35 \%$ with 0.5 and $1.0 \mathrm{mM} \mathrm{CdCl}_{2}$, respectively and Gly II activity significantly decreased by $20 \%$ and $32 \%$ with 0.5 and $1.0 \mathrm{mM} \mathrm{CdCl}_{2}$, respectively. However, after pretreatment of $\mathrm{Na}_{2} \mathrm{SeO}_{4}$, they observed both enzymes of the glyoxalase system significantly upregulated. Later on, Hasanuzzaman and Fujita [16] recorded the same trend in wheat plants under arsenic (As) stress. Both Gly I and Gly II activities decreased under As stress in wheat plants, which upregulated after using SNP as exogenous protectant. However, rice plants under $150 \mu \mathrm{M} \mathrm{CuSO}_{4}$ stress for $48 \mathrm{~h}$ significantly increased Gly I and Gly II activities in both leaves and roots [95]. Both Gly I and Gly II activities further increased in roots after pretreatment of SA; however, in leaves, Gly I activity increased further by 50\%, and Gly II activity remain unchanged. On the other hand, Mostofa et al. [96] reported that Gly I and Gly II activities increased significantly in rice plants exposed to $100 \mu \mathrm{M} \mathrm{CuSO}_{4}$ for $48 \mathrm{~h}$. However, no significant differences were observed in glyoxalase system enzymes after SNP treatment; even GSH treatment decreased enzyme activity. Mostofa et al. [79] conducted an experiment with rice plants (BRRI dhan29) under $100 \mu \mathrm{M} \mathrm{CuSO}_{4}$ stress for 4 and 7 days and found activity of the glyoxalase system damaged in a time-dependent manner. They recorded that MG increased by $106 \%$ and $156 \%$ after 4 and 7 days of stress, respectively; Gly I activity increased by $22 \%$ after 4 days of stress treatment and decreased by $25 \%$ after 7 days of stress and Gly II activity increased by $47 \%$ after 4 days of stress, but the activity returned to the level in the control after 7 days of stress. However, pre-treatment with $10 \mathrm{mM}$ Tre for $48 \mathrm{~h}$ upregulated the enzymes of the glyoxalase system and reduced the production of toxic MG. Rahman et al. [69] observed that rice seedlings under 0.5 and $1 \mathrm{mM} \mathrm{Na}_{2} \mathrm{HAsO}_{4}$ stress for 5 days decreased Gly I activity by $9 \%$ and $17 \%$, respectively, but increased Gly II activity as well as MG content. However, combined treatment of $10 \mathrm{mM} \mathrm{CaCl}_{2}$ and $\mathrm{Na}_{2} \mathrm{HAsO}_{4}$ stress showed higher Gly I and Gly II activities. MG content also decreased by $22 \%$ and $25 \%$ at 0.5 and $1 \mathrm{mM} \mathrm{Na}_{2} \mathrm{HAsO}_{4}$-treated rice seedlings, respectively. Both 0.25 and $0.5 \mathrm{mM} \mathrm{CdCl}_{2}$ stress for $72 \mathrm{~h}$ in rice plants increased MG content with the decline of Gly I and Gly II activities [91]. However, cotreatment of $2.5 \mathrm{mM} \mathrm{CaCl}_{2}$ with stress decreased MG content by $31 \%$ and $24 \%$ at 0.25 and $0.5 \mathrm{mM}$ Cd-treated seedlings, respectively, increased Gly I activity by $35 \%$ and $31 \%$ at 0.25 and $0.5 \mathrm{mM} \mathrm{Cd}$-treated seedlings, respectively, and increased Gly II activity by $23 \%$ and $53 \%$ with 0.25 and $0.5 \mathrm{mM} \mathrm{Cd}$ exposure, respectively. Recently, Rahman et al. [92] reported that rice plants under $\mathrm{Cd}$ stress showed high MG content due to inefficient activity of enzymes of the glyoxalase system, 
but co-application of $0.3 \mathrm{mM} \mathrm{MnSO}_{4}$ upregulated the Gly I and Gly II enzymes, which lessened the MG level. In V. radiata, $1.5 \mathrm{mM} \mathrm{CdCl}_{2}$ stress for $48 \mathrm{~h}$ increased MG content by $132 \%$ with increased Gly I and decreased Gly II activities [21]. On the other hand, use of exogenous protectant increased the activity of Gly II enzyme and decreased the cytotoxic MG level. Very recently, Nahar et al. [22] observed that MG content increased by $77 \%$ and $177 \%$ under 1.0 and $1.5 \mathrm{mM} \mathrm{CdCl}_{2}$, respectively, in mung bean plants with increased Gly I and decreased Gly II activities. However, pretreatment of $0.25 \mathrm{mM}$ spermine (Spm) for $24 \mathrm{~h}$ in mung bean plant reduced the MG level with the slight increase in Gly I and marked increase in Gly II activities. The above findings indicate that the increase in MG content is a common response of plants to a metal stress, and that the glyoxalase system primarily tries to detoxify the MG but becomes unable under severe stress. However, the use of diverse exogenous protectants can overcome these problems at certain levels by maintaining elevated Gly I and Gly II activities, thus creating the possibility of upregulating the GSH level and the GSH/GSSG ratio via the glyoxalase system. The high GSH levels assist in the synthesis of the phytochelatin and these questration of the heavy metal phytochelatin complex into the vacuole $[21,23,93,94]$.

\subsection{Extreme Temperatures}

High temperatures beyond plants' tolerance levels lead to physiological disorder and catastrophic loss of crop productivity (Table 4) [5,6]. High temperature stress results in malfunctioning of PS II and decreases electron transport efficiency, which are the reasons for the overproduction of ROS in plants [97]. Disrupting the activities of the glyoxalase system, HT enhances the production of cytotoxic MG [18,22]. Low temperature also induces overproduction of ROS and MG because of the disruption of antioxidant defense and glyoxalase systems, respectively which is same as effects of other abiotic stresses $[17,20]$. Understanding the mechanism of damage by HT or LT is fundamental for the development of tolerant plant species. 
Table 2. Regulation of the glyoxalase system and associated antioxidant defense system in plants under drought stress.

\begin{tabular}{|c|c|c|c|c|c|}
\hline $\begin{array}{l}\text { Plant } \\
\text { Species }\end{array}$ & $\begin{array}{l}\text { Stress (Dose } \\
\text { and Duration) }\end{array}$ & Changes in Glyoxalase and Antioxidant Defense Systems & Protectants & $\begin{array}{l}\text { Changes in Glyoxalase and Antioxidant } \\
\text { Defense Systems after Protection }\end{array}$ & Reference \\
\hline V. radiata & $\begin{array}{l}5 \% \text { PEG-6000, } \\
\quad 48 \mathrm{~h}\end{array}$ & $\begin{array}{ll}\text { - } & \text { Increased MG } \\
\text { - } & \text { Increased Gly I activity but decreased Gly II activity } \\
\text { - } & \text { Increased GSSG content, and ratio of GSH/GSSG } \\
\text { Increased ROS generation and oxidative damage }\end{array}$ & $\begin{array}{l}0.2 \mathrm{mM} \\
\text { Spermidine } \\
\quad(\mathrm{Spd})\end{array}$ & $\begin{array}{ll}\text { - } & \text { Increased Gly II activity } \\
\text { - } & \text { Increased GSH and GSSG contents } \\
\text { - } & \text { Reduced MG level } \\
\text { - } & \text { Reduced ROS production including } \mathrm{H}_{2} \mathrm{O}_{2} \text { and } \mathrm{O}_{2}{ }^{\bullet-} \text { as } \\
& \text { well as lipid peroxidation }\end{array}$ & [22] \\
\hline V. radiata & $\begin{array}{l}25 \% \text { PEG-6000, } \\
24 \text { and } 48 \mathrm{~h}\end{array}$ & $\begin{array}{ll}\text { - } & \text { Increased MG content } \\
\text { - } & \text { Decreased activity of Gly II } \\
\text { - } & \text { Increased } \mathrm{H}_{2} \mathrm{O}_{2} \text { and } \mathrm{O}_{2}{ }^{-}-\text {contents and lipid peroxidation }\end{array}$ & $1 \mathrm{mM} \mathrm{GSH}$ & $\begin{array}{ll}\text { - } & \text { Increased activities of Gly I and Gly II } \\
\text { - } & \text { Decreased } \mathrm{MG} \text { content } \\
\text { - } & \text { Decreased } \mathrm{H}_{2} \mathrm{O}_{2} \text { and } \mathrm{O}_{2} \bullet-\text { contents and } \\
& \text { lipid peroxidation }\end{array}$ & [19] \\
\hline B. juncea & $\begin{array}{l}\text { Water deficit } \\
\text { stress }\end{array}$ & $\begin{array}{ll}\text { - } & \text { Upregulation of Gly I activity } \\
\text { - } & \text { Increased MG content } \\
\end{array}$ & - & 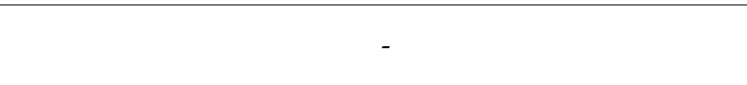 & [66] \\
\hline $\begin{array}{c}\text { S. } \\
\text { lycopersicum }\end{array}$ & $\begin{array}{l}\text { Water deficit } \\
\text { stress created by } \\
\text { mannitol }\end{array}$ & $\begin{array}{l}\text { - Tomato (encoding gene for Gly I) upregulated Gly I } \\
\text { activity by 2-3-fold in all cell types of roots, stems, and } \\
\text { leaves especially in phloem sieve elements }\end{array}$ & - & - & [87] \\
\hline B. napus & $\begin{array}{l}10 \% \text { and } 20 \% \\
\text { PEG-6000, } 48 \mathrm{~h}\end{array}$ & $\begin{array}{l}\text { - } \quad \text { Gly I activity increased but Gly II activity decreased } \\
\text { - The content of GSH and GSSG increased, GSH/GSSG } \\
\text { ratio decreased } \\
\text { - } \\
\mathrm{H}_{2} \mathrm{O}_{2} \text { and MDA contents increased } \\
\end{array}$ & $\begin{array}{c}25 \mu \mathrm{M} \\
\mathrm{Na}_{2} \mathrm{SeO}_{4}\end{array}$ & $\begin{array}{ll}\text { - } & \text { Increased activities of Gly I, and Gly II } \\
\text { - } & \text { Increase in GSH content and GSH/GSSG ratio } \\
\text { - } & \text { Reduction of ROS generation and oxidative damage }\end{array}$ & [14] \\
\hline O. sativa & Desiccation, $8 \mathrm{~h}$ & $\begin{array}{l}\text { Overexpression of OsDJ-1C increased Gly III activity, } \\
\text { decreased MG content, increased formation of D-lactate in } \\
\text { GSH-dependent manner }\end{array}$ & - & - & [25] \\
\hline
\end{tabular}


Table 3. Regulation of the glyoxalase system and the associated antioxidant defense system in plants exposed to toxic metals/metalloids.

\begin{tabular}{|c|c|c|c|c|c|}
\hline $\begin{array}{c}\text { Plant } \\
\text { Species }\end{array}$ & $\begin{array}{l}\text { Stress (Dose } \\
\text { and Duration) }\end{array}$ & $\begin{array}{l}\text { Changes in Glyoxalase and } \\
\text { Antioxidant Defense Systems }\end{array}$ & Protectants & $\begin{array}{l}\text { Changes in Glyoxalase and Antioxidant } \\
\text { Defense Systems after Protection }\end{array}$ & Reference \\
\hline$V$. radiata & $\begin{array}{l}1 \mathrm{mMCdCl}_{2} \\
\quad 48 \mathrm{~h}\end{array}$ & $\begin{array}{l}\text { - Slightly increased activity of Gly I } \\
\text { - } \quad \text { Decreased Gly II activity } \\
\text { - Higher accumulation of MG }\end{array}$ & $\begin{array}{l}5 \mathrm{mM} \text { Pro or GB, } \\
\quad 48 \mathrm{~h}\end{array}$ & $\begin{array}{l}\text { - } \quad \text { Further increase in Gly I activity } \\
\text { - } \quad \text { Increased Gly II activity } \\
\text { - } \quad \text { Lower oxidative damage due to higher MG detoxification }\end{array}$ & [93] \\
\hline B. napus & $\begin{array}{l}0.5 \text { and } 1.0 \mathrm{mM} \\
\mathrm{CdCl}_{2}, 48 \mathrm{~h}\end{array}$ & $\begin{array}{l}\text { - Gly I activity decreased by } 18 \% \text { and } 35 \% \text { at } 0.5 \text { and } \\
1.0 \mathrm{mM} \mathrm{CdCl}_{2} \text {, respectively } \\
\text { - Gly II activity decreased by } 20 \% \text { and } 32 \% \text { at } 0.5 \text { and } \\
1.0 \mathrm{mM} \mathrm{CdCl}_{2} \text {, respectively }\end{array}$ & $\begin{array}{l}\text { Seed pretreatment; } \\
50 \text { and } 100 \mu \mathrm{M} \\
\mathrm{Na}_{2} \mathrm{SeO}_{4}, 24 \mathrm{~h}\end{array}$ & $\begin{array}{l}\text { - } \quad \text { Further increase in Gly I activity } \\
\text { - } \quad \text { Gly II activity increased }\end{array}$ & [94] \\
\hline T. aestivum & $\begin{array}{l}0.25 \text { and } 0.5 \mathrm{mM} \\
\mathrm{Na}_{2} \mathrm{HAsO}_{4} \cdot 7 \mathrm{H}_{2} \mathrm{O} \\
\quad 72 \mathrm{~h}\end{array}$ & $\begin{array}{l}\text { - } \quad \text { Decreased Gly I activity by } 34 \% \text { and } 44 \% \text { at } 0.25 \text { and } \\
0.5 \mathrm{mM} \text { of As, respectively } \\
\text { - } \quad \text { Decreased Gly II activity by } 29 \% \text { only upon } 0.5 \mathrm{mM} \text { As } \\
\text { - } \quad \text { Insufficient MG detoxification }\end{array}$ & $0.25 \mathrm{mM}$ SNP, $72 \mathrm{~h}$ & $\begin{array}{ll}\text { - } & \text { Increased Gly I and Gly II activities } \\
\text { - } & \text { Efficient MG detoxification }\end{array}$ & [16] \\
\hline O. sativa & $\begin{array}{l}150 \mu \mathrm{M} \mathrm{CuSO}_{4} \\
48 \mathrm{~h}\end{array}$ & $\begin{array}{l}\text { - } \quad \text { Enhanced Gly I activity } \\
\text { Gly II activity increased by } 24 \% \text { in leaves and 30\% } \\
\text { in roots }\end{array}$ & $\begin{array}{l}\text { Pretratment, } \\
100 \mu \mathrm{M} \mathrm{SA}, 24 \mathrm{~h}\end{array}$ & $\begin{array}{l}\text { - } \quad \text { Further enhancement of Gly I activities in roots and leaves } \\
\text { - Enhanced Gly II activities by } 50 \% \text { in roots but remain } \\
\text { statistically similar in leaves }\end{array}$ & [95] \\
\hline O. sativa & $\begin{array}{l}100 \mu \mathrm{M} \mathrm{CuSO}_{4} \\
48 \mathrm{~h}\end{array}$ & - Increased Gly I and Gly II activities & $\begin{array}{c}200 \mu \mathrm{M} \text { SNP or } \\
200 \mu \mathrm{M} \text { GSH, } 48 \mathrm{~h}\end{array}$ & $\begin{array}{l}\text { - } \quad \text { Decreased Gly I and Gly II activities } \\
\text { - Increased GSH content } \\
\end{array}$ & [96] \\
\hline O. sativa & $\begin{array}{l}100 \mu \mathrm{M} \mathrm{CuSO}_{4} \\
4 \text { and } 7 \text { days }\end{array}$ & $\begin{array}{l}\text { - Gly I activity increased by } 22 \% \text { after } 4 \text { days stress and } \\
\text { decreased by } 25 \% \text { after } 7 \text { days stress } \\
\text { - Gly II activity increased by } 47 \% \text { after } 4 \text { days stress, but } \\
\text { the activity returned to the level in control after Day } 7 \\
\text { - Increased MG level by } 106 \% \text { and } 156 \% \text { after } 4 \text { and } 7 \\
\text { days stress, respectively }\end{array}$ & $\begin{array}{l}\text { Pretreatment, } \\
10 \mathrm{mM} \text { Tre, } 48 \mathrm{~h}\end{array}$ & $\begin{array}{l}\text { - } \quad \text { Gly I activity increased at both days of Cu stress } \\
\text { - } \quad \text { Ily II activity did not increase significantly at Day } 4 \text {, but } \\
\text { increased significantly at Day } 7 \\
\text { - Decreased MG level by } 27 \% \text { and } 35 \% \text { at } 4 \text { and } 7 \text { days } \\
\text { stress, respectively }\end{array}$ & [79] \\
\hline O. sativa & $\begin{array}{l}0.5 \text { and } 1 \mathrm{mM} \\
\mathrm{Na}_{2} \mathrm{HAsO}_{4} \\
5 \text { days }\end{array}$ & $\begin{array}{l}\text { - } \quad \text { Decrease in Gly I activity by } 9 \% \text { and } 17 \% \text { at } 0.5 \text { and } \\
1 \mathrm{mM} \text { As, respectively } \\
\text { - } \quad \text { Increased Gly II activity } \\
\text { - } \quad \text { MG content increased with dose-dependent manner }\end{array}$ & $\begin{array}{l}10 \mathrm{mM} \mathrm{CaCl}_{2} \\
(\mathrm{Ca}), 5 \text { days }\end{array}$ & $\begin{array}{l}\text { - Higher Gly I activity } \\
\text { - Increased Gly II activity by } 23 \% \text { and } 31 \% \text { at } 0.5 \text { and } 1 \mathrm{mM} \\
\text { - As treated seedlings } \\
\text { MG content decreased by } 22 \% \text { and } 25 \% \text { at } 0.5 \text { and } 1 \mathrm{mM} \\
\text { As treated rice seedlings, respectively }\end{array}$ & [69] \\
\hline
\end{tabular}


Table 3. Cont

\begin{tabular}{|c|c|c|c|c|c|}
\hline $\begin{array}{l}\text { Plant } \\
\text { Species }\end{array}$ & $\begin{array}{l}\text { Stress (Dose } \\
\text { and Duration) }\end{array}$ & $\begin{array}{l}\text { Changes in Glyoxalase and } \\
\text { Antioxidant Defense Systems }\end{array}$ & Protectants & $\begin{array}{l}\text { Changes in Glyoxalase and Antioxidant } \\
\text { Defense Systems after Protection }\end{array}$ & Reference \\
\hline O. sativa & $\begin{array}{l}0.25 \text { and } 0.5 \mathrm{mM} \\
\mathrm{CdCl}_{2}, 72 \mathrm{~h}\end{array}$ & $\begin{array}{ll}\text { - } & \text { Reduced Gly I activity } \\
\text { - } & \text { Declined Gly II activity } \\
\text { - } & \text { Increased MG content with dose-dependent manner }\end{array}$ & $\begin{array}{l}2.5 \mathrm{mM} \mathrm{CaCl}_{2} \\
72 \mathrm{~h}\end{array}$ & $\begin{array}{l}\text { - Increased Gly I activity by } 35 \% \text { and } 31 \% \text { at } 0.25 \text { and } \\
0.5 \mathrm{mM} \mathrm{CdCl}_{2} \text {, respectively } \\
\text { - Increased } \mathrm{Gly}_{\mathrm{II}} \text { activity by } 23 \% \text { and } 53 \% \text { with } 0.25 \text { and } \\
0.5 \mathrm{mM} \mathrm{CdCl}_{2} \text {, respectively } \\
\text { - Decreased } \mathrm{MG}_{\text {G }} \text { content by } 31 \% \text { and } 24 \% \text { at } 0.25 \text { and } \\
0.5 \mathrm{mM} \mathrm{CdCl}_{2} \text {, respectively }\end{array}$ & [91] \\
\hline O. sativa & $\begin{array}{l}0.3 \mathrm{mM} \mathrm{CdCl}_{2} \\
\quad 72 \mathrm{~h}\end{array}$ & $\begin{array}{ll}\text { - } & \text { Increased Gly I activity } \\
\text { - } & \text { Decreased Gly II activity } \\
\text { - } & \text { Increased MG content }\end{array}$ & $\begin{array}{l}0.3 \mathrm{mM} \mathrm{MnSO}_{4} \\
72 \mathrm{~h}\end{array}$ & $\begin{array}{l}\text { - } \quad \text { Decreased the MG content } \\
\text { - } \quad \text { Increased the Gly I activity } \\
\text { - } \quad \text { Further increase in Gly II activity }\end{array}$ & [92] \\
\hline V. radiata & $\begin{array}{c}1.5 \mathrm{mM} \mathrm{CdCl}_{2} \\
48 \mathrm{~h}\end{array}$ & $\begin{array}{l}\text { - } \quad \text { Increased Gly I activity } \\
\text { - } \quad \text { Decreased Gly II activity } \\
\text { - } \quad \text { Increased MG production by } 132 \%\end{array}$ & $\begin{array}{l}\text { Pretreatment, } \\
0.2 \mathrm{mM} \text { Put and } \\
1 \mathrm{mM} \text { SNP, } 24 \mathrm{~h}\end{array}$ & $\begin{array}{ll}- & \text { Increased Gly II activity } \\
\text { - } & \text { Decreased MG content }\end{array}$ & [21] \\
\hline V. radiata & $\begin{array}{l}\mathrm{CdCl}_{2}, 1.0 \text { and } \\
1.5 \mathrm{mM}\end{array}$ & $\begin{array}{ll}\text { - } & \text { Increased Gly I activity } \\
\text { - } & \text { Decreased Gly II activity } \\
\text { - } & \text { Increased MG content by } 77 \% \text { and } 177 \% \text { under } 1.0 \text { and } \\
& 1.5 \mathrm{mM} \mathrm{CdCl}_{2} \text {, respectively }\end{array}$ & $\begin{array}{l}\text { Pretreatment, } \\
0.25 \mathrm{mM} \mathrm{Spm}, 24 \mathrm{~h}\end{array}$ & $\begin{array}{ll}\text { - } & \text { Slight increase in Gly I activity } \\
\text { - } & \text { Markedly increased Gly II activity } \\
& \text { Reduced MG content }\end{array}$ & [23] \\
\hline
\end{tabular}


Ficus concinna seedlings were grown under HT stress of $35^{\circ} \mathrm{C}$ (considered as moderate HT stress) and $40^{\circ} \mathrm{C}$ (considered as severe stress) and their performance were compared with the control seedlings (grown under $28^{\circ} \mathrm{C}$ ). The activity of Gly II increased under both levels of HT stresses. However, Gly I activity increased only at moderate HT stress. High temperature stress showed damaging effects by increasing the MG level and inducing oxidative stress through the generation of $\mathrm{ROS}\left(\mathrm{O}_{2}{ }^{\bullet-}\right.$ and $\left.\mathrm{H}_{2} \mathrm{O}_{2}\right)$ and the increase in MDA and MG content. The reductions in chl levels and relative water content were noticed in HT-affected seedlings [98]. A coordinated induction of glyoxalase and antioxidant defense systems has been documented in mung bean seedlings under HT stress. High temperature stress $\left(40{ }^{\circ} \mathrm{C}, 2\right.$ days) resulted in a high increase in MG and increased Gly I activity, but decreased Gly II activity, increased GSH content, and a decreased GSH/GSSG ratio in mung bean seedlings. Increased $\mathrm{H}_{2} \mathrm{O}_{2}$ and $\mathrm{O}_{2}{ }^{\bullet-}$ generation and decreased AsA content and AsA/DHA ratios have been noticed in HT-affected seedlings. Differential modulations of enzymes of antioxidant defense system were observed under HT stress, and these modulations include the reduction in CAT, MDHAR, and DHAR activities and increased APX, GR, GPX, and GST activities. High temperatures also decreased water content, increased Pro content, destroyed chl pigment, and decreased the seedlings' vigor and biomass accumulation [22]. The leaf discs from transgenic tobacco plants subjected to $44^{\circ} \mathrm{C}$ exhibited higher AKR activity and was responsible for accumulating a lower amount of MG in their leaves, compared to the wild-type plants with either a presence or absence of HT stress, which improved HT stress tolerance [59]. Overexpression of OsglyII resulted in the rapid accumulation of Gly II in rice under HT $\left(45^{\circ} \mathrm{C}\right)$ and LT stress $\left(4^{\circ} \mathrm{C}\right)$ [99]. Temperature shock was reported to transduce signal through $\mathrm{Ca}^{2+}$, which binds to specific target proteins, such as kinases, which in turn activated Gly I [100]. Low temperature stress $\left(6^{\circ} \mathrm{C}\right)$ increased $\mathrm{MG}$ content, $\mathrm{H}_{2} \mathrm{O}_{2}$ content, and lipid peroxidation and decreased Gly II activity, water content, and growth in mung bean seedlings. The Gly I activity remained unaltered, but Gly II activity decreased, which was the cause of the increase in MG content in both 2 and 3 days of LT stresses [17]. High temperature treatment $\left(38^{\circ} \mathrm{C}, 24\right.$ and $\left.48 \mathrm{~h}\right)$ increased Gly I and Gly II activities, MDA, and $\mathrm{H}_{2} \mathrm{O}_{2}$ levels, but decreased the chl content in T. aestivum $\mathrm{L}$. cv. Pradip. Modulation of antioxidant system components have been demonstrated in HT-affected wheat seedlings. Ascorbate content decreased, GSH and GSSG content increased, the GSH/GSSG ratio decreased, and the activities of APX, GR, GPX, and GST increased upon HT exposure [13]. Most recently, the enzyme Gly III's efficiency in depleting MG has been shown in a shorter pathway. Oryza sativa L. cv. IR64 overexpressing OsDJ-1C was exposed to 4 and $42{ }^{\circ} \mathrm{C}$ for $8 \mathrm{~h}$. Increased activity of Gly III enzyme has been documented with a decreased level of MG and the simultaneous formation of D-lactate, indicating the role of OsDJ-1C as a GLY III enzyme converting MG directly into D-lactate in a GSH-independent manner [25]. 
Table 4. Regulation of the glyoxalase system and associated antioxidant defense system in plants under temperature stress.

\begin{tabular}{|c|c|c|c|c|c|}
\hline $\begin{array}{c}\text { Plant } \\
\text { Species }\end{array}$ & $\begin{array}{c}\text { Extent of } \\
\text { Temperature Stress }\end{array}$ & $\begin{array}{l}\text { Changes in Glyoxalase and } \\
\text { Antioxidant Defense Systems }\end{array}$ & Protectants & $\begin{array}{l}\text { Changes in Glyoxalase and Antioxidant } \\
\text { Defense Systems after Protection }\end{array}$ & Reference \\
\hline F. concinna & 35 and $40^{\circ} \mathrm{C}, 48 \mathrm{~h}$ & $\begin{array}{l}\text { - Increased MG content and Gly II activity but } \\
\text { decreased Gly I activity }\end{array}$ & $\begin{array}{c}0.25 \mu \mathrm{M} \\
\text { 24-epibrassinolide } \\
\text { (EBR) }\end{array}$ & $\begin{array}{l}\text { - } \quad \text { Increased activities of Gly I and Gly II } \\
\text { - }\end{array}$ & [98] \\
\hline O. sativa & $45^{\circ} \mathrm{C}, 15-120 \mathrm{~min}$ & $\begin{array}{l}\text { - Overexpression of OsglyII resulted in rapid } \\
\text { accumulation of Gly II }\end{array}$ & - & - & [99] \\
\hline O. sativa & $42^{\circ} \mathrm{C}, 8 \mathrm{~h}$ & $\begin{array}{l}\text { - Overexpressing OsDJ-1C the Gly III activity had } \\
\text { been increased, decreased MG content, increased } \\
\text { formation of D-lactate in GSH-dependent manner }\end{array}$ & - & - & [25] \\
\hline V. radiata & $40^{\circ} \mathrm{C}, 2$ days & $\begin{array}{ll} & \text { Overproduction of MG } \\
\text { - } & \text { Increased Gly I activity, decreased Gly II activity } \\
\text { - } & \text { Increased GSH content, decreased GSH/GSSG } \\
& \text { ratio, increased } \mathrm{H}_{2} \mathrm{O}_{2} \text { and } \mathrm{O}_{2}{ }^{\bullet-} \text { generation } \\
\end{array}$ & $\begin{array}{c}\text { Spermine } \\
(\mathrm{Spm}, 0.2 \mathrm{mM})\end{array}$ & $\begin{array}{ll}\text { - } & \text { Reduced MG content } \\
\text { - } & \text { Increased Gly I and Gly II activities } \\
\text { - } & \text { Increased } \mathrm{GSH} \text { content and GSH/GSSG ratio } \\
\text { - } & \text { Decreased } \mathrm{H}_{2} \mathrm{O}_{2} \text { and } \mathrm{O}_{2}{ }^{\bullet-} \text { production } \\
\end{array}$ & [22] \\
\hline T. aestivum & $38^{\circ} \mathrm{C}, 24$ and $48 \mathrm{~h}$ & $\begin{array}{ll}\text { - } & \text { Increased Gly I and Gly II activities } \\
\text { - } & \text { Increased GSH and GSSG contents but decreased } \\
\text { GSH/GSSG ratio, increased } \mathrm{H}_{2} \mathrm{O}_{2} \text { content and } \\
\text { lipid peroxidation }\end{array}$ & $0.5 \mathrm{mM}$ SNP & $\begin{array}{ll}\text { - } & \text { Increased Gly I activity } \\
\text { - } & \text { Increased GSH level as well as the GSH/GSSG ratio } \\
& \text { Decreased } \mathrm{H}_{2} \mathrm{O}_{2} \text { content and lipid peroxidation }\end{array}$ & [13] \\
\hline V. radiata & $6^{\circ} \mathrm{C}, 2$ and 3 days & $\begin{array}{ll}\text { - } & \text { Increased MG content, } \mathrm{H}_{2} \mathrm{O}_{2} \text { content and } \\
& \text { lipid peroxidation } \\
\text { - } & \text { Decreased Gly II activity }\end{array}$ & $0.25 \mathrm{mM}$ Spd & $\begin{array}{l}\text { - } \quad \text { Reduced oxidative stress induced by both MG and } \\
\text { ROS decreased GSSG and increased GSH content and } \\
\text { GSH/GSSG ratio }\end{array}$ & [17] \\
\hline O. sativa & $4{ }^{\circ} \mathrm{C}, 8 \mathrm{~h}$ & $\begin{array}{l}\text { - Overexpression of OsDJ-1C, increase in } \\
\text { Gly III activity } \\
\text { Decrease in MG content, increased formation } \\
\text { of D-lactate }\end{array}$ & - & 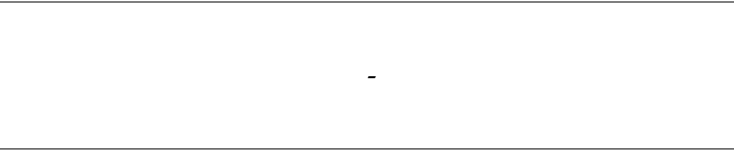 & [25] \\
\hline O. sativa & $4^{\circ} \mathrm{C}, 15 \mathrm{~min}-2 \mathrm{~h}$ & $\begin{array}{l}\text { Overexpression of OsglyII and higher } \\
\text { accumulation of Gly II }\end{array}$ & - & - & [99] \\
\hline
\end{tabular}




\section{Role of Methylglyoxal as a Signaling Molecule}

At normal growing conditions, the basal level of MG in plants is $30-75 \mu \mathrm{M}[8,42,82]$. However, under stress, the amount of MG increases. Therefore, it is possible that MG may take part in signaling pathways in plants. The signaling role of MG is explained in a study by Hoque et al. [27]. They reported that MG can induce stomatal closure by modulating ROS production and cytosolic-free calcium concentration in the Arabidopsis leaf guard cells. MG-induced stomatal closure without involving endogenous abscisic acid (ABA) or endogenous methyl jasmonate is worth noting. In another study, Hoque et al. [28] reported that the MG-induced stomatal closure in Arabidopsis is due to the inhibition of $\mathrm{K}^{+}$influx into the guard cells. Furthermore, the involvement of MG in the regulation of ABA-induced signaling pathways was shown by Hoque et al. [101]. In their study, MG induced the expression of $\mathrm{RD}$ (responsive to dehydration) genes (RD29A and RD29B) in Arabidopsis, whereas an aba2-2 mutant (ABA-deficient mutant) showed no expression of $R D 29 B$ and $R A B 18$ (responsive to ABA gene) genes. Recently, microarray analysis of rice treated with MG showed the upregulation or downregulation of genes involved in signal transduction and abiotic and biotic stress responses. Exogenous MG affected the genes that control the complex signal transduction pathway. Signals are transmitted from cytosol to nucleus through phosphorylation or dephosphorylation of protein kinases. Therefore, a number of transcription regulatory proteins such as $D R E B, M Y B, N A C, W R K Y$, and $A P 2$ domain-containing proteins, were modified due to MG exposure. Most of the transcription factors that are altered due to MG are known to play role in biotic and abiotic stresses in plants. Thus, there may be a cross-talk between MG-responsive and stress-responsive signal transduction pathways in plants. In addition to plants, MG also plays a role in signal transduction in animals, bacteria, and yeast $[40,41]$. Furthermore, it is worth noting that the MG responsive element, $7-8 \mathrm{bp}$ long conserved elements in the promoter region of the genes, has been identified in rice by microarray analysis [40]. Though the possible pathways of MG-induced signal transduction have been determined and are shown in Figure 4, the concrete mechanism is yet to be explored in plants.

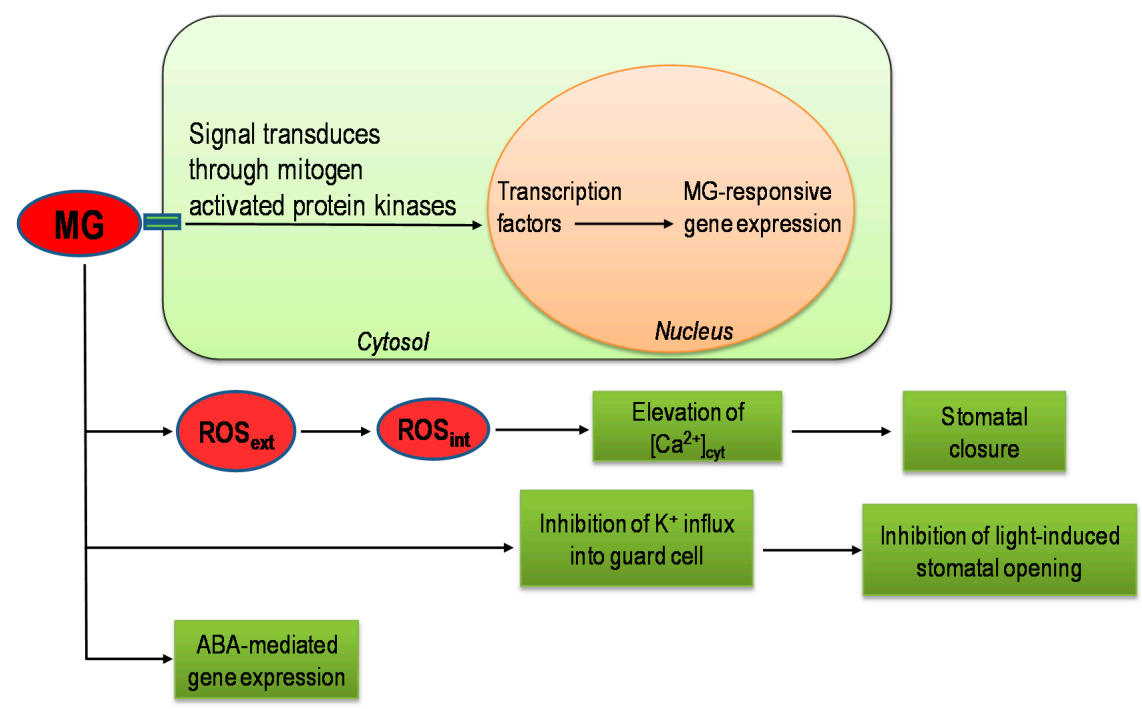

Figure 4. MG signaling pathways in plants (Modified from Hoque et al. [49] and Kaur et al. [40,41]) $\left(\right.$ ROS $_{\text {ext }}$, extracellular ROS; ROS int, Intracellular ROS; $\left[\mathrm{Ca}^{2+}\right]_{\text {cyt }}$, cytosolic $\mathrm{Ca}^{2+}$ ).

\section{Genetic Manipulation in Enhancing Glyoxalase Pathway in Plants}

Engineering of the glyoxalase pathway has been documented to enhance abiotic stress tolerance in different plant species (Table 5). The GLX2-1 gene expression is upregulated in wild A. thaliana under salt, anoxia, and excess L-threonine stresses, indicating the essential roles of glyoxalase system enzymes under stress conditions [102]. Transgenic tobacco underexpressing Gly I accumulated significantly 
higher content of MG and showed inhibition of seed germination under different abiotic stress conditions (salinity, $200 \mathrm{mM}$; cold, $4{ }^{\circ} \mathrm{C}$; drought stress, withholding watering). In contrast, in Gly I overexpressing (NtSgly I) transgenic tobacco, MG content did not increase much in response to different abiotic stresses, compared to the untransformed plants. Moreover, the supplementation of exogenous GSH reduced MG levels in both untransformed and transgenic plants [42]. Overexpression of the gly I gene resulted in a higher activity of the Gly I enzyme in transgenic $V$. mungo that improved the ability to withstand salt stress. The transgenic line also showed improved germination and growth under salt stress [103]. The cDNA encoding Gly I was cloned and characterized from B. juncea, and transgenic tobacco plants overexpressing Gly I were developed. The transgenic tobacco plants were tolerant to MG and high salt. The degree of Gly I expression was positively correlated to various levels of salt stresses, indicating the pivotal role of Gly I in ensuring salt stress tolerance [66]. Overexpression of TcGLX1 increased levels of Gly I, decreased metal accumulation, and improved root growth under zinc stress. Transgenic Thlaspi caerulescens also showed similar tolerance response to $\mathrm{Cd}$ and lead [104]. Transgenic T. aestivum overexpressing TaGly I was exposed to $\mathrm{NaCl}$ and $\mathrm{ZnCl}_{2}$ stresses. However, transgenic tobacco showed higher tolerance to $\mathrm{ZnCl}_{2}$ stress, compared to the control [105]. Transgenic Carrizo citrange rootstocks overexpressing Gly I (BjGlyI) and Gly II genes (PgGlyII) were examined and compared with the wild type for its salt $(75 \mathrm{mM} \mathrm{NaCl})$ stress tolerance capacity. The wild type showed yellowing and marginal burn in lower leaves, whereas the phenotypic performance of the transgenic plants was better, compared to the wild type. The dry weight of the root, shoot, and whole plant was higher in the transgenic plant that those of the wild plant. The reason behind the better performance of the transgenic plant was due to a smaller accumulation of $\mathrm{Na}^{+}$and $\mathrm{Cl}^{-}$ions, compared to the wild-type plant. Therefore, the heterologous expression of glyoxalase system genes improved salt stress tolerance in Carrizo citrange [106]. Sugar beet M14 line encoding M14 glyoxalase I is an interspecific hybrid between a wild species Beta corolliflora Zoss and a cultivated species B. vulgaris. Upon expression of M14 glyoxalase I, the transgenic sugar beet showed improved tolerance to $\mathrm{MG}$, salt, mannitol, and $\mathrm{H}_{2} \mathrm{O}_{2}$ stresses, compared to the wild type [107]. Oryza sativa L. cv. IR64 overexpressed OsDJ-1C has been reported as a Gly III enzyme. Methylglyoxal is directly converted into D-lactate in a GSH-independent manner due to Gly III activity. Thus, overexpression of OsDJ-1C increased the formation of D-lactate as a result of the depletion of MG, where the activity of Gly III was involved [25]. The expression of Bj glyII in B. juncea was upregulated by salinity, heavy metal stress, and ABA, where the activity of Gly II enzyme also increased [108]. Transcript profusion of GLY $I$ and GLY II genes in rice was studied in response to various abiotic stresses including salt, drought, osmotic, cold, heat, oxidative, genotoxic, wounding, and UV/B stress and at different developmental stages [109]. Overexpression of OsGLYI-11.2 in tobacco plants reduced MG content and decreased the $\mathrm{Na}^{+} / \mathrm{K}^{+}$ratio and the maintenance of reduced glutathione levels under $200 \mathrm{mM} \mathrm{NaCl}$ or $1 \mathrm{mM}$ $\mathrm{MG}$ or $5 \mathrm{mM} \mathrm{H}_{2} \mathrm{O}_{2}$ stresses [110]. Upregulation of the Gly I enzyme activity had been reported in glyII, overexpressing transgenic tobacco plants that showed reduced $\mathrm{Na}^{+}$sequestration in the young leaves [68]. Overexpression of OsglyII showed higher tolerance to toxic concentrations of MG and $\mathrm{NaCl}$ in rice seedlings. The activity of Gly II increased under toxic concentrations of $\mathrm{MG}$ and $\mathrm{NaCl}$ stresses. Transgenic plants showed improved growth, increased shoot and root $\mathrm{K}^{+}$content, and better ion balance (ratio of $\mathrm{Na}^{+} / \mathrm{K}^{+}$) under salt stress [67]. Again, transgenic tobacco plants overexpressing the genes for Gly I and Gly II enzymes were exposed to $5 \mathrm{mM} \mathrm{ZnCl}_{2}$ for $24 \mathrm{~h}$. These tobacco plants showed a lower level of toxic $\mathrm{Zn}$ accumulation, and the reason behind this was the maintenance of the level of phytochelatins and glutathione homeostasis. Transgenic plants also showed better growth and flowering behavior, and they set normal viable seeds, better yield, MG accumulation, and less lipid peroxidation exposed to toxic level of $\mathrm{Zn}$ [67]. 
Table 5. Genetic modifications of glyoxalase genes and their role in conferring abiotic stress tolerance.

\begin{tabular}{|c|c|c|c|c|}
\hline Transgenic Plant & Gene & Gene Sources & Tolerance Response in Transgenic Plant & References \\
\hline $\begin{array}{l}\text { Beta corolliflora } \times \\
\quad \text { B. vulgaris }\end{array}$ & BvM14-glyoxalase I & B. corolliflora and B. vulgaris & $\begin{array}{l}\text { - Improved tolerance to } \mathrm{MG} \text {, salt, mannitol and } \mathrm{H}_{2} \mathrm{O}_{2} \text { stresses } \\
\text { - Improved chl content and growth, compared to control under the abiotic stress conditions }\end{array}$ & [107] \\
\hline N. tabacum & TaGly I & T. aestivum & $\begin{array}{l}\text { - Both Gly I and Gly II were overexpressed, which enhanced zinc tolerance } \\
\text { - Improved chl content, reduced yellowing, and improved phenotype }\end{array}$ & [105] \\
\hline N. tabacum & TcGLX1 & B. juncea & $\begin{array}{l}\text { - Increased levels of Gly I, decreased metal accumulation and improved root growth under zinc stress } \\
\text { - Transgenics also showed similar tolerance response to } \mathrm{Cd} \text { and } \mathrm{Pb}\end{array}$ & [104] \\
\hline N. tabacum & Gly I cDNA & B. juncea & - Activity of Gly I increased in transgenic plants showed higher tolerance to MG and high salt & [66] \\
\hline O. sativa & OsDJ-1C & Arabidopsis sp. & - Increased Gly III activity, decreased MG content under desiccation stress & [25] \\
\hline O. sativa & OsDJ-1C & A. thaliana & $\begin{array}{l}\text { - Overexpression of } O s D J-1 C \text {, increase in Gly III activity, decrease in MG content } \\
\text { - Increased formation of D-lactate }\end{array}$ & [25] \\
\hline C. Citrange & BjGlyI and $P g G l y I I$ & $\begin{array}{l}\text { BjGlyI from B. juncea and PgGlyII } \\
\quad \text { from Pennisetum glaucum }\end{array}$ & $\begin{array}{l}\text { - Reduced plant yellowing and leaf burn symptom } \\
\text { - Increased root, shoot and plant dry weight, and reduced accumulation of } \mathrm{Na}^{+} \text {and } \mathrm{Cl}^{-} \text {ion, } \\
\text { compared to wild type }\end{array}$ & [106] \\
\hline B. juncea & Bj glyII & $\begin{array}{l}\text { P. glaucum, O. sativa, Arabidopsis, } \\
\text { and C. arietinum }\end{array}$ & - Salinity, HM stress, and ABA upregulated the activity of Gly II enzyme & [108] \\
\hline O. sativa & OsglyII & O. sativa & $\begin{array}{l}\text { - Activity of Gly II increased under toxic concentrations of } \mathrm{MG} \text { and } \mathrm{NaCl} \text { stresses } \\
\text { - Transgenic plants showed improved growth, increased shoot and root } \mathrm{K}^{+} \text {content and better ion } \\
\text { balance }\left(\text { ratio of } \mathrm{Na}^{+} / \mathrm{K}^{+} \text {) under salt stress }\right.\end{array}$ & [67] \\
\hline N. tabaccum & gly I and gly II & $\begin{array}{l}\text { gly I from B. juncea, gly II gene } \\
\text { isolated from O. sativa }\end{array}$ & - Improved salinity tolerance & [68] \\
\hline N. tabacum & gly I and gly II & $\begin{array}{l}\text { gly I from B. juncea, gly II gene } \\
\text { isolated from O. sativa }\end{array}$ & $\begin{array}{l}\text { - Transgenic plants showed } 15 \% \text { to } 50 \% \text { increase in Gly I activity, and } 300 \% \text { to } 400 \% \text { increase in Gly } \\
\text { II activity } \\
\text { - Reduced toxic } \mathrm{Zn} \text { accumulation due to maintenance of phytochelatin and GSH content } \\
\text { - Improved growth, flowering behavior and set normal viable seeds, better yield }\end{array}$ & [88] \\
\hline N. tabacum & OsGLYI-11.2 & O. sativa & $\begin{array}{l}\text { - Reduced MG, decreased } \mathrm{Na}^{+} / \mathrm{K}^{+} \text {ratio and maintenance of reduced glutathione levels under } 200 \mathrm{mM} \\
\mathrm{NaCl} \text { or } 1 \mathrm{mM} \mathrm{MG} \text { or } 5 \mathrm{mM} \mathrm{H}_{2} \mathrm{O}_{2}\end{array}$ & [110] \\
\hline
\end{tabular}




\section{Conclusions and Outlook}

In this review, we accommodate information from existing research findings and available reviews regarding the glyoxalase and antioxidant defense systems, and their pivotal functions in diminishing oxidative stress and cytotoxic effects on plants under different abiotic stresses. However, an array of laps and gaps remain behind these. Thus, questions arise on different issues. Is there any direct interaction between the glyoxalase and antioxidant defense systems since both of these systems utilize GSH-dependent pathways to detoxify ROS and MG, respectively $[11,12,14,16,18-20,25,26]$ ? Methylglyoxal catalyzes the photoreduction of $\mathrm{O}_{2}$ to $\mathrm{O}_{2}{ }^{\bullet-}$ at photosystem I, and ROS production also has other pathways; is there any interaction among these pathways [26]? Very few reports indicate the signaling function of ROS and MG in plants [27-29]. However, the glyoxalase system has been studied widely in animal systems. Glyoxalase I and II have been purified and characterized from some plant species. Moreover, a very recent report explored the presence of Gly III proteins in plants, which performs the function of direct conversion of MG to D-lactate. Identification of this shorter route for MG detoxification is a signpost in the field of glyoxalase system study [25]. Higher ALR activity under stress conditions might have roles in reducing MG content, which further decreased ROS production, but it requires further investigation [89]. Upregulation of glyoxalase enzymes has been documented with the phytohormone accumulation together with rapid cell growth $[87,111,112]$. In plants, the roles of the glyoxalase system are not well defined. Moreover, exploration of the biological implication of this pathway under stress is just beginning. Therefore, study of the glyoxalase system in correlation with the antioxidant defense systems demands insightful research.

Acknowledgments: We are very thankful to M.H.M. Borhannuddin Bhuyan, Taufika Islam Anee, Tasnim Farha Bhuiyanand Mazhar Ul Alam, Laboratory of Plant Stress Responses, Faculty of Agriculture, Kagawa University, Japan for their critical reading and formatting of the manuscript draft. The first author acknowledges the Japan Society for the Promotion of Science (JSPS) for funding in his research. We are also very thankful to Md. Rumainul Islam, Environment Engineering Program, Chongqing University and Md. Mosfeq-Ul-Hasan, Zhejiang University, Hangzhou, China, for providing us with several supporting articles. As page limitation precluded us from citing a large number of studies, we apologize to those whose original publications are therefore not directly referenced in this paper.

Author Contributions: Mirza Hasanuzzaman performed literature reviews and drafted the manuscript; Kamrun Nahar, Md. Shahadat Hossain, Jubayer Al Mahmud, Anisur Rahman, and Masashi Inafuku contributed the review for literature research; Masayuki Fujita and Hirosuke Oku reviewed the manuscript and approved the final draft.

Conflicts of Interest: The authors declare no conflict of interest.

\section{Abbreviations}

$\begin{array}{ll}\text { AKR } & \text { aldo-keto reductase } \\ \text { ALR } & \text { aldose/aldehyde reductase } \\ \text { APX } & \text { ascorbate peroxidase } \\ \text { AsA } & \text { ascorbate } \\ \text { chl } & \text { chlorophyll } \\ \text { CAT } & \text { catalase } \\ \text { DHA } & \text { dehydroascorbic acid } \\ \text { DHAP } & \text { dihydroxyacetone phosphate } \\ \text { DHAR } & \text { dehydroascorbate reductase } \\ \text { ETC } & \text { electron transport chain } \\ \text { GAP } & \text { glyceraldehyde-3-phosphate } \\ \text { Gly } & \text { glyoxalase } \\ \text { GR } & \text { glutathione reductase } \\ \text { GSH } & \text { reduced glutathione } \\ \text { GSSG } & \text { oxidized glutathione }\end{array}$




$\begin{array}{ll}\text { GPX } & \text { glutathione peroxidase } \\ \text { GST } & \text { glutathione } s \text {-transferase } \\ \text { HT } & \text { high temperature } \\ \text { LOX } & \text { lipoxygenase } \\ \text { LT } & \text { low temperature } \\ \text { MDHAR } & \text { monodehydroascorbate reductase } \\ \text { MG } & \text { methylglyoxal } \\ \text { MGdG } & \text { 3-(2'-deoxyribosyl)-6,7-dihydro-6,7-dihydroxy-6/7-methylimidazo-[2,3-b]purine-9(8)one } \\ \text { MV } & \text { methyl viologen } \\ \text { NADPH } & \text { nicotinamide adenine dinucleotide phosphate } \\ \text { PEG } & \text { polyethylene glycol } \\ \text { PS II } & \text { photosystem II } \\ \text { Pro } & \text { proline } \\ \text { ROS } & \text { reactive oxygen species } \\ \text { RWC } & \text { relative water content } \\ \text { SLG } & s \text {-D-lactoyl-glutathione } \\ \text { SOD } & \text { superoxide dismutase } \\ \text { SNP } & \text { sodium nitroprusside } \\ \text { Spd } & \text { spermidine } \\ \text { Spm } & \text { spermine } \\ \text { Tre } & \text { trehalose }\end{array}$

\section{References}

1. IPCC. Climate change and water. In Technical Paper of the Intergovernmental Panel for Climate Change; Bates, B.C., Kundzewicz, Z.W., Palutikof, J., Wu, S., Eds.; Secretariat: Geneva, Switzerland, 2008; p. 210.

2. Mittler, R.; Blumwald, E. Genetic engineering for modern agriculture: Challenges and perspectives. Annu. Rev. Plant Biol. 2010, 61, 443-462. [CrossRef] [PubMed]

3. Acquaah, G. Principles of Plant Genetics and Breeding; Blackwell: Oxford, UK, 2007; p. 385.

4. Hasanuzzaman, M.; Hossain, M.A.; Teixeira da Silva, J.A.; Fujita, M. Plant responses and tolerance to abiotic oxidative stress: Antioxidant defense is a key factor. In Crop Stress and its Management: Perspectives and Strategies; Bandi, V., Shanker, A.K., Shanker, C., Mandapaka, M., Eds.; Springer: Berlin, Germany, 2012; pp. 261-316.

5. Hasanuzzaman, M.; Nahar, K.; Alam, M.M.; Roychowdhury, R.; Fujita, M. Physiological, biochemical, and molecular mechanisms of heat stress tolerance in plants. Int. J. Mol. Sci. 2013, 14, 9643-9684. [CrossRef] [PubMed]

6. Hasanuzzaman, M.; Nahar, K.; Fujita, M. Extreme temperatures, oxidative stress and antioxidant defense in plants. In Abiotic Stress_Plant Responses and Applications in Agriculture; Vahdati, K., Leslie, C., Eds.; InTech: Rijeka, Yugoslavia, 2013; pp. 169-205.

7. Tsukahara, K.; Sawada, H.; Kohno, Y.; Matsuura, T.; Mori, I.C.; Terao, T. Ozone-induced rice grain yield loss is triggered via a change in panicle morphology that is controlled by aberrant panicle organization 1 Gene. PLoS ONE 2015, 10, e0123308. [CrossRef] [PubMed]

8. Yadav, S.K.; Singla-Pareek, S.L.; Ray, M.; Reddy, M.K.; Sopory, S.K. Methylglyoxal levels in plants under salinity stress are dependent on glyoxalase I and glutathione. Biochem. Biophys. Res. Commun. 2005, 337, 61-67. [CrossRef] [PubMed]

9. Chaplen, F.W.R. Incidence and potential implications of the toxic metabolite methylglyoxal in cell culture: A review. Cytotechnology 1998, 26, 173-183. [CrossRef] [PubMed]

10. Gill, S.S.; Tuteja, N. Reactive oxygen species and antioxidant machinery in abiotic stress tolerance in crop plants. Plant Physiol. Biochem. 2010, 48, 909-930. [CrossRef] [PubMed]

11. Hasanuzzaman, M.; Hossain, M.A.; Fujita, M. Selenium-induced upregulation of the antioxidant defense and methylglyoxal detoxification system reduces salinity-induced damage in rapeseed seedlings. Biol. Trace Elem Res. 2011, 143, 1704-1721. [CrossRef] [PubMed] 
12. Hasanuzzaman, M.; Hossain, M.A.; Fujita, M. Nitric oxide modulates antioxidant defense and the methylglyoxal detoxification system and reduces salinity-induced damage of wheat seedlings. Plant Biotechnol. Rep. 2011, 5, 353-365. [CrossRef]

13. Hasanuzzaman, M.; Nahar, K.; Alam, M.M.; Fujita, M. Exogenous nitric oxide alleviates high temperature induced oxidative stress in wheat (Triticum aestivum L.) seedlings by modulating the antioxidant defense and glyoxalase system. Aust. J. Crop Sci. 2012, 6, 1314-1323.

14. Hasanuzzaman, M.; Fujita, M. Selenium pretreatment upregulates the antioxidant defense and methylglyoxal detoxification system and confers enhanced tolerance to drought stress in rapeseed seedlings. Biol. Trace Elem. Res. 2011, 143, 1758-1776. [CrossRef] [PubMed]

15. Hasanuzzaman, M.; Fujita, M. Exogenous silicon treatment alleviates salinity-induced damage in Brassica napus L. seedlings by upregulating the antioxidant defense and methylglyoxal detoxification system. In Proceedings of the Annual Meeting of the American Society of Plant Biologists, Minniapolis, MN, USA, 6-10 August 2011.

16. Hasanuzzaman, M.; Fujita, M. Exogenous sodium nitroprusside alleviates arsenic-induced oxidative stress in wheat (Triticum aestivum L.) seedlings by enhancing antioxidant defence and glyoxalase system. Ecotoxicology 2013, 22, 584-596. [CrossRef] [PubMed]

17. Nahar, K.; Hasanuzzaman, M.; Alam, M.M.; Fujita, M. Exogenous spermidine alleviates low temperature injury in mung bean (Vigna radiata L.) seedlings by modulating ascorbate-glutathione and glyoxalase pathway. Int. J. Mol. Sci. 2015, 16, 30117-30132. [CrossRef] [PubMed]

18. Nahar, K.; Hasanuzzaman, M.; Alam, M.A.; Fujita, M. Exogenous glutathione confers high temperature stress tolerance in mung bean (Vigna radiata L.) by modulating antioxidant defense and methylglyoxal detoxification system. Environ. Exp. Bot. 2015, 112, 44-54. [CrossRef]

19. Nahar, K.; Hasanuzzaman, M.; Alam, M.M.; Fujita, M. Glutathione-induced drought stress tolerance in mung bean: Coordinated roles of the antioxidant defence and methylglyoxal detoxification systems. AoB Plants 2015, 7, plv069. [CrossRef] [PubMed]

20. Rajwanshi, R.; Kumar, D.; Yusuf, M.; DebRoy, S.; Sarin, N. Stress-inducible overexpression of glyoxalase I is preferable to its constitutive overexpression for abiotic stress tolerance in transgenic Brassica juncea. Mol. Breed. 2016, 36, 1-15. [CrossRef]

21. Nahar, K.; Hasanuzzaman, M.; Alam, M.M.; Rahman, A.; Suzuki, T.; Fujita, M. Polyamine and nitric oxide crosstalk: Antagonistic effects on cadmium toxicity in mung bean plants through upregulating the metal detoxification, antioxidant defense and methylglyoxal detoxification systems. Ecotoxicol. Environ. Saf. 2016, 126, 245-255. [CrossRef] [PubMed]

22. Nahar, K.; Hasanuzzaman, M.; Alam, M.M.; Rahman, A.; Mahmud, J.A.; Suzuki, T.; Fujita, M. Insights into spermine-induced combined high temperature and drought tolerance in mung bean: Osmoregulation and roles of antioxidant and glyoxalase system. Protoplasma 2016. [CrossRef] [PubMed]

23. Nahar, K.; Rahman, M.; Hasanuzzaman, M.; Alam, M.M.; Rahman, A.; Suzuki, T.; Fujita, M. Physiological and biochemical mechanisms of spermine-induced cadmium stress tolerance in mung bean (Vigna radiata $\mathrm{L}$.) seedlings. Environ. Sci. Pollut. Res. 2016, 23, 21206-21218. [CrossRef] [PubMed]

24. Nahar, K.; Hasanuzzaman, M.; Rahman, A.; Alam, M.M.; Mahmud, J.A.; Suzuki, T.; Fujita, M. Polyamines confer salt tolerance in mung bean (Vigna radiata L.) by reducing sodium uptake, improving nutrient homeostasis, antioxidant defense, and methylglyoxal detoxification systems. Front. Plant Sci. 2016, 7, 1104. [CrossRef] [PubMed]

25. Ghosh, A.; Kushwaha, H.R.; Hasan, M.R.; Pareek, A.; Sopory, S.K.; Singla-Pareek, S.L. Presence of unique glyoxalase III proteins in plants indicates the existence of shorter route for methylglyoxal detoxification. Sci. Rep. 2016, 6, 18358. [CrossRef] [PubMed]

26. Saito, R.; Yamamoto, H.; Makino, A.; Sugimoto, T.; Miyake, C. Methylglyoxal functions as hill oxidant and stimulates the photoreductin of $\mathrm{O}_{2}$ at photosystem I: A symptom of plant diabetes. Plant Cell Environ. 2011, 34, 1454-1464. [CrossRef] [PubMed]

27. Hoque, M.A.; Uraji, M.; Banu, M.N.A.; Mori, I.C.; Nakamura, Y.; Murata, Y. Methylglyoxal inhibition of cytosolic ascorbate peroxidase from Nicotiana tabacum. J. Biochem. Mol. Toxicol. 2012, 26, 315-321. [CrossRef] [PubMed] 
28. Hoque, T.S.; Uraji, M.; Ye, W.; Hossain, M.A.; Nakamura, Y.; Murata, Y. Methylglyoxal-induced stomatal closure accompanied by peroxidase-mediated ROS production in Arabidopsis. J. Plant Physiol. 2012, 169, 979-986. [CrossRef] [PubMed]

29. Schieber, M.; Chandel, N.S. ROS Function in redox signaling and oxidative stress. Curr. Biol. 2014, 24, 453-462. [CrossRef] [PubMed]

30. Bartosz, G. Oxidative stress in plants. Acta Physiol. Plant. 1997, 19, 47-64. [CrossRef]

31. Apel, K.; Hirt, H. Reactive oxygen species: Metabolism, oxidative stress and signal transduction. Annu. Rev. Plant Mol. Biol. 2004, 55, 373-399. [CrossRef] [PubMed]

32. Logan, B. Reactive oxygen species and photosynthesis. In Antioxidants and Reactive Oxygen Species in Plants; Smrinoff, N., Ed.; Blackwell: Oxford, UK, 2005; pp. 250-267.

33. Kim, K.; Portis, J. Oxygen-dependent $\mathrm{H}_{2} \mathrm{O}_{2}$ production by Rubisco. FEBS Lett. 2004, 571, 124-128. [CrossRef] [PubMed]

34. Guo, Z.; Ou, W.; Lu, S.; Zhong, Q. Differential responses of antioxidant system to chilling and drought in four rice cultivars differing in sensitivity. Plant Physiol. Biochem. 2006, 44, 828-836. [CrossRef] [PubMed]

35. Ahmed, S.; Nawata, E.; Hosokawa, M.; Domae, Y.; Sakuratani, T. Alterations in photosynthesis and some antioxidant enzymatic activities of mungbean subjected to waterlogging. Plant Sci. 2002, 163, 117-123. [CrossRef]

36. Sharma, S.S.; Dietz, K.J. The relationship between metal toxicity and cellular redox imbalance. Trends Plant Sci. 2008, 14, 43-50. [CrossRef] [PubMed]

37. Srivastava, S.; Tripathi, R.D.; Dwivedi, U.N. Synthesis of phytochelatins and modulation of antioxidants in response to cadmium stress in Cuscuta reflexa-An angiospermic parasite. J. Plant Physiol. 2004, 161, 665-674. [CrossRef] [PubMed]

38. Qadir, S.; Qureshi, M.I.; Javed, S.; Abdin, M.Z. Genotypic variation in phytoremediation potential of Brassica juncea cultivars exposed to Cd stress. Plant Sci. 2004, 167, 1171-1181. [CrossRef]

39. Dong, J.; Wu, F.B.; Zhang, G.P. Influence of cadmium on antioxidant capacity and four microelement concentrations in tomato (Lycopersicon esculentum). Chemosphere 2006, 64, 1659-1666. [CrossRef] [PubMed]

40. Kaur, C.; Kushwaha, H.R.; Mustafiz, A.; Pareek, A.; Sopory, S.K.; Singla-Pareek, S.L. Analysis of global gene expression profile of rice in response to methylglyoxal indicates its possible role as a stress signal molecule. Front. Plant Sci. 2015, 6, 682. [CrossRef] [PubMed]

41. Kaur, C.; Sharma, S.; Singla-Pareek, S.L.; Sopory, S.K. Methylglyoxal, triose phosphateisomerase and glyoxalase pathway: Implications in abiotic stress and signaling in plants. In Elucidation of Abiotic Stress Signaling in Plants; Pandey, G.K., Ed.; Springer: New York, NY, USA, 2015; pp. 347-366.

42. Yadav, S.K.; Singla-Pareek, S.L.; Ray, M.; Reddy, M.K.; Sopory, S.K. Transgenic tobacco plants overexpressing glyoxalase enzymes resist an increase in methylglyoxal and maintain higher reduced glutathione levels under salinity stress. FEBS Lett. 2005, 579, 6265-6271. [CrossRef] [PubMed]

43. Yadav, S.K.; Singla-Pareek, S.L.; Sopory, S.K. An overview on the role of methylglyoxal and glyoxalases in plants. Drug Metabol. Drug Interact. 2008, 23, 51-68. [CrossRef] [PubMed]

44. Thornalley, P.J. Glutathione-dependent detoxification of $\alpha$-oxoaldehydesby the glyoxalase system: Involvement in disease mechanisms and antiproliferative activity of glyoxalase I inhibitors. Chem. Biol. Interact. 1998, 111-112, 137-151. [CrossRef]

45. Thornalley, P.J. Protein and nucleotide damage by glyoxal and methylglyoxal in physiological systems-Role in ageing and disease. Drug Metabol. Drug Interact. 2008, 23, 125-150. [CrossRef] [PubMed]

46. Rabbani, N.; Thornalley, P.J. Methylglyoxal, glyoxalase 1 and the dicarbonyl proteome. Amino Acids 2012, 42, 1133-1142. [CrossRef] [PubMed]

47. Rabbani, N.; Thornalley, P.J. Dicarbonyl proteome and genome damage in metabolic and vascular disease. Biochem. Soc. Trans. 2014, 42, 425-432. [CrossRef] [PubMed]

48. Kaur, C.; Singla-Pareek, S.L.; Sopory, S.K. Glyoxalase and methylglyoxal as biomarkers for plant stress tolerance. Crit. Rev. Plant Sci. 2014, 33, 429-456. [CrossRef]

49. Hoque, T.S.; Hossain, M.A.; Mostofa, M.G.; Burritt, D.J.; Fujita, M.; Tran, L.S.P. Methylglyoxal: An emerging signaling molecule in plant abiotic stress responses and tolerance. Front. Plant Sci. 2016, 7, 1341. [CrossRef] [PubMed]

50. Mankikar, S.; Rangekar, P. Effects of methylglyoxal on germination of barley. Fyton 1974, 32, 9-16. 
51. Engqvist, M.K.M.; Drincovich, M.F.; Flügge, U.I.; Maurino, V.G. Two D-2-hydroxy-acid dehydrogenases in Arabidopsis thaliana with catalytic capacities to participate in the last reactions of themethylglyoxal and $\beta$-oxidation pathways. J. Biol. Chem. 2009, 284, 25026-25037. [CrossRef] [PubMed]

52. Wienstroer, J.; Engqvist, M.K.M.; Kunz, H.H.; Flügge, U.I.; Maurino, V.G. D-Lactate dehydrogenase as a marker gene allows positive selection oftransgenic plants. FEBS Lett. 2012, 586, 36-40. [CrossRef] [PubMed]

53. Mano, J.; Miyatake, F.; Hiraoka, E.; Tamoi, M. Evaluation of the toxicity of stress-related aldehydes to photosynthesis in chloroplasts. Planta 2009, 230, 639-648. [CrossRef] [PubMed]

54. Murata, K.; Fukuda, Y.; Watanabe, K.; Saikusa, T.; Shimosaka, M.; Kimura, A. Characterization of methylglyoxal synthase in Saccharomyces cerevisiae. Biochem. Biophys. Res. Commun. 1985, 131, 190-198. [CrossRef]

55. Richard, J.P. Mechanism for the formation of methylglyoxal from triosephosphates. Biochem. Soc. Trans. 1993, 21, 549-553. [CrossRef] [PubMed]

56. Kalapos, M.P. Methylglyoxal in living organisms: Chemistry, biochemistry, toxicology and biological implications. Toxicol. Lett. 1999, 110, 145-175. [CrossRef]

57. Hossain, M.A.; Hossain, M.Z.; Fujita, M. Stress-induced changes of methylglyoxal level and glyoxalase I activity in pumpkin seedlings and cDNA cloning of glyoxalase I gene. Aust. J. Crop Sci. 2009, 3, 53-64.

58. Hegedüs, A.; Erdei, S.; Janda, T.; Tóth, E.; Horváth, G.; Dudits, D. Transgenictobacco plants overproducing alfalfa aldose/aldehydes reductase show highertolerance to low temperature and cadmium stress. Plant Sci. 2004, 166, 1329-1333. [CrossRef]

59. Turóczy, Z.; Kis, P.; Török, K.; Cserháti, M.; Lendvai, A.; Dudits, D.; Horváth, G.V. Overproduction of a rice aldo-keto reductase increases oxidative and heat stress tolerance by malondialdehyde and methylglyoxal detoxification. Plant Mol. Biol. 2011, 75, 399-412. [CrossRef] [PubMed]

60. Hossain, M.A.; Teixeira da Silva, J.A.; Fujita, M. Glyoxalase system and reactive oxygen species detoxification system in plant abiotic stress response and tolerance: An intimate relationship. In Abiotic Stress in Plants-Mechanisms and Adaptations; Shanker, A.K., Ed.; Intech: Rejika, Yugoslavia, 2011; pp. 235-266.

61. Neuberg, C. The destruction of lactic aldehyde and methylglyoxal by animal organs. Biochem. J. 1913, 49, 502-506.

62. Dakin, H.D.; Dudley, H.W. An enzyme concerned with the formation of hydroxyl acids from ketonic aldehydes. J. Biol. Chem. 1913, 14, 155-157.

63. Norton, S.J.; Talesa, V.; Yuan, W.J.; Principato, G.B. Glyoxalase I and Glyoxalase II from Aloevera: Purification, characterization and comparison with animal glyoxalases. Biochem. Int. 1990, 22, 411-418. [PubMed]

64. Maiti, M.K.; Krishnasamy, S.; Owen, H.A.; Makaroff, C.A. Molecular characterization of glyoxalase II from Arabidopsis thaliana. Plant Mol. Biol. 1997, 35, 471-481. [CrossRef] [PubMed]

65. Racker, E. The mechanism of action of glyoxalase. J. Biol. Chem. 1951, 190, 685-696. [PubMed]

66. Reddy, V.S.; Sopory, S.K. Glyoxalase I from Brassica juncea: Molecular cloning, regulation and its over-expression confer tolerance in transgenic tobacco under stress. Plant J. 1999, 17, 385-395. [CrossRef]

67. Singla-Pareek, S.L.; Yadav, S.K.; Pareek, A.; Reddy, M.K.; Sopory, S.K. Enhancing salt tolerance in a crop plant by overexpression of glyoxalase II. Transgenic Res. 2008, 17, 171-180. [CrossRef] [PubMed]

68. Singla-Pareek, S.L.; Reddy, M.K.; Sopory, S.K. Genetic engineering of the glyoxalase pathway in tobacco leads to enhanced salinity tolerance. Proc. Natl. Acad. Sci. USA 2003, 100, 14672-14677. [CrossRef] [PubMed]

69. Rahman, A.; Mostofa, M.G.; Alam, M.M.; Nahar, K.; Hasanuzzaman, M.; Fujita, M. Calcium mitigates arsenic toxicity in rice seedlings by reducing arsenic uptake and modulating the antioxidant defense and glyoxalase systems and stress markers. BioMed Res. Int. 2015. [CrossRef] [PubMed]

70. Simpson, P.J.; Tantitadapitak, C.; Reed, A.M.; Mather, O.C.; Bunce, C.M.; White, S.A.; Ride, J.P. Characterization of two novel aldo-keto reductases from Arabidopsis: Expression patterns, broad substratespecificity, and an open active-site structure suggest a role in toxicant metabolism following stress. J. Mol. Biol. 2009, 392, 465-480. [CrossRef] [PubMed]

71. Yamauchi, Y.; Hasegawa, A.; Taninaka, A.; Mizutani, M.; Sugimoto, Y. NADPH-dependent reductases involved in the detoxification of reactive carbonyls in plants. J. Biol. Chem. 2011, 286, 6999-7009. [CrossRef] [PubMed] 
72. Kumar, D.; Singh, P.; Yusuf, M.A.; Upadhyaya, C.P.; Roy, S.D.; Hohn, T.; Sarin, N.B. The Xerophytaviscosa aldose reductase (ALDRXV4) confers enhanced drought and salinity tolerance to transgenic tobacco plants by scavenging methylglyoxal and reducing the membrane damage. Mol. Biotechnol. 2013, 54, 292-303. [CrossRef] [PubMed]

73. Narawongsanont, R.; Kabinpong, S.; Auiyawong, B.; Tantitadapitak, C. Cloning and characterization of AKR4C14, a rice aldo-keto reductase, from Thai Jasmine rice. Protein J. 2012, 31, 35-42. [CrossRef] [PubMed]

74. Hoque, M.A.; Uraji, M.; Banu, M.N.A.; Mori, I.C.; Nakamura, Y.; Murata, Y. The effects of methylglyoxal on glutathione S-transferase from Nicotiana tabacum. Biosci. Biotechnol. Biochem. 2010, 74, 2124-2126. [CrossRef] [PubMed]

75. Kaur, C.; Ghosh, A.; Pareek, A.; Sopory, S.K.; Singla-Pareek, S.L. Glyoxalases and stress tolerance in plants. Biochem. Soc. Trans. 2014, 42, 485-490. [CrossRef] [PubMed]

76. Hasanuzzaman, M.; Alam, M.M.; Nahar, K.; Al-Mahmud, J.; Ahamed, K.U.; Fujita, M. Exogenous salicylic acid alleviates salt stress-induced oxidative damage in Brassica napus by enhancing the antioxidant defense and glyoxalase systems. Aust. J. Crop Sci. 2014, 8, 631-639.

77. Hasanuzzaman, M.; Alam, M.M.; Rahman, A.; Hasanuzzaman, M.; Nahar, K.; Fujita, M. Exogenous proline and glycine betaine mediated upregulation of antioxidant defense and glyoxalase systems provides better protection against salt-induced oxidative stress in two rice (Oryza sativa L.) varieties. BioMed Res. Int. 2014. [CrossRef]

78. Mostofa, M.G.; Saegusa, D.; Fujita, M.; Tran, L.P. Hydrogen sulfide regulates salt tolerance in rice by maintaining $\mathrm{Na}^{+} / \mathrm{K}^{+}$balance, mineral homeostasis and oxidative metabolism under excessive salt stress. Front. Plant Sci. 2015, 6, 1055. [CrossRef] [PubMed]

79. Mostofa, M.G.; Hossain, M.A.; Fujita, M.; Tran, L.S. Physiological and biochemical mechanisms associated with trehalose-induced copper-stress tolerance in rice. Sci. Rep. 2015, 5, 11433. [CrossRef] [PubMed]

80. Rahman, A.; Nahar, K.; Hasanuzzaman, M.; Fujita, M. Calcium supplementation improves $\mathrm{Na}^{+} / \mathrm{K}^{+}$ratio, antioxidant defense and glyoxalase systems in salt-stressed rice seedlings. Front. Plant Sci. 2016, 7, 609. [CrossRef] [PubMed]

81. Rahman, A.; Hossain, M.S.; Mahmud, J.; Nahar, K.; Hasanuzzaman, M.; Fujita, M. Manganese-induced salt stress tolerance in rice seedlings: Regulation of ion homeostasis, antioxidant defense and glyoxalase systems. Physiol. Mol. Biol. Plants 2016. [CrossRef] [PubMed]

82. Yadav, S.K.; Singla-Pareek, S.L.; Reddy, M.K.; Sopory, S.K. Methylglyoxal detoxification by glyoxalase system: A survival strategy during environmental stresses. Physiol. Mol. Biol. Plants 2005, 11, 1-11.

83. Hossain, M.A.; Fujita, M. Evidence for a role of exogenous glycinebetaine and proline in antioxidant defense and methylglyoxal detoxification systems in mung bean seedlings under salt stress. Physiol. Mol. Biol. Plants 2010, 16, 19-29. [CrossRef] [PubMed]

84. Hossain, M.A.; Mostofa, M.G.; Fujita, M. Heat-shock positively modulates oxidative protection of salt and drought-stressed mustard (Brassica campestris L.) seedlings. J. Plant Sci. Mol. Breed. 2013. [CrossRef]

85. Mostofa, M.G.; Hossain, M.A.; Fujita, M. Trehalose pretreatment induces salt tolerance in rice (Oryza sativa L.) seedlings: Oxidative damage and co-induction of antioxidantdefense and glyoxalase systems. Protoplasma 2015, 252, 461-475. [CrossRef] [PubMed]

86. Hasanuzzaman, M.; Nahar, K.; Gill, S.S.; Fujita, M. Drought stress responses in plants, oxidative stress, and antioxidant defense. In Climate Change and Plant Abiotic Stress Tolerance; Tuteja, N., Gill, S.S., Eds.; Wiley: Weinheim, Germany, 2014; pp. 209-250.

87. Espartero, J.; Sanchez-Aguayo, I.; Pardo, J.M. Molecular characterization of glyoxalase-I from a higher plant; upregulation by stress. Plant Mol. Biol. 1995, 29, 1223-1233. [CrossRef] [PubMed]

88. Singla-Pareek, S.L.; Yadav, S.K.; Pareek, A.; Reddy, M.K.; Sopory, S.K. Transgenic tobacco overexpressing glyoxalase pathway enzymes grow and set viable seeds in zinc-spiked soils. Plant Physiol. 2006, 140, 613-623. [CrossRef] [PubMed]

89. Hideg, É.; Nagy, T.; Oberschall, A.; Dudits, D.; Vass, I. Detoxification function of aldose/aldehyde reductase during drought and ultraviolet-B (280-320 nm) stresses. Plant Cell Environ. 2003, 26, 513-522. [CrossRef]

90. Oberschall, A.; Deák, M.; Török, K.; Sass, L.; Vass, I.; Kovács, I.; Fehér, A.; Dudits, D.; Horváth, G.V. A novel aldose/aldehyde reductase protects transgenic plants against lipid peroxidation under chemical and drought stress. Plant J. 2000, 24, 437-446. [CrossRef] [PubMed] 
91. Rahman, A.; Mostofa, M.G.; Nahar, K.; Hasanuzzaman, M.; Fujita, M. Exogenous calcium alleviates cadmium-induced oxidative stress in rice (Oryza sativa L.) seedlings by regulating the antioxidant defense and glyoxalase systems. Braz. J. Bot. 2016, 39, 393-407.

92. Rahman, A.; Nahar, K.; Hasanuzzaman, M.; Fujita, M. Manganese-induced cadmium stress tolerance in rice seedlings: Coordinated action of antioxidant defense, glyoxalase system and nutrient homeostasis. C. R. Biol. 2016. [CrossRef] [PubMed]

93. Hossain, M.A.; Hasanuzzaman, M.; Fujita, M. Upregulation of antioxidant and glyoxalase systems by exogenous glycinebetaine and proline in mung bean confer tolerance to cadmium stress. Physiol. Mol. Biol. Plants 2010, 16, 259-272. [CrossRef] [PubMed]

94. Hasanuzzaman, M.; Hossain, M.A.; Fujita, M. Exogenous selenium pretreatment protects rapeseed seedlings from cadmium-induced oxidative stress by upregulating the antioxidant defense and methylglyoxal detoxification systems. Biol. Trace Elem. Res. 2012, 149, 248-261. [CrossRef] [PubMed]

95. Mostofa, M.G.; Fujita, M. Salicylic acid alleviates copper toxicity in rice (Oryza sativa L.) seedlings by upregulating antioxidative and glyoxalase systems. Ecotoxicology 2013, 22, 959-973. [CrossRef] [PubMed]

96. Mostofa, M.G.; Seraj, Z.I.; Fujita, M. Exogenous sodium nitroprusside and glutathione alleviate copper toxicity by reducing copper uptake and oxidative damage in rice (Oryza sativa L.) seedlings. Protoplasma 2014, 251, 1373-1386. [CrossRef] [PubMed]

97. Wang, X.; Cai, J.; Liu, F.; Dai, T.; Cao, W.; Wollenweber, B.; Jiang, D. Multiple heat priming enhances thermo-tolerance to a later high temperature stress via improving subcellular antioxidant activities in wheat seedlings. Plant Physiol.Biochem. 2014, 74, 185-192. [CrossRef] [PubMed]

98. Jin, S.; Li, X.Q.; Wang, G.G.; Zhu, X.T. Brassinosteroids alleviate high-temperature injury in Ficusconcinna seedlings via maintaining higher antioxidant defence and glyoxalase systems. AoB Plants 2015, 7, plv009. [CrossRef] [PubMed]

99. Yadav, S.K.; Singla-Pareek, S.L.; Kumar, M.; Pareek, A.; Saxena, M.; Sarin, N.B.; Sopory, S.K. Characterization and functional validation of glyoxalase II from rice. Protein Exp. Purif. 2007, 51, 126-132. [CrossRef] [PubMed]

100. Snedden, W.A.; Fromm, H. Calmodulin, calmodulin-related proteins and plant responses to the environment. Trends Plant Sci. 1998, 3, 299-304. [CrossRef]

101. Hoque, T.S.; Uraji, M.; Tuya, A.; Nakamura, Y.; Murata, Y. Methylglyoxal inhibits seed germination and root elongation and upregulates transcription of stress-responsive genes in ABA-dependent pathway in Arabidopsis. Plant Biol. 2012, 14, 854-858. [CrossRef] [PubMed]

102. Devanathan, S.; Erban, A.; Rodolfo, P.J.; Kopka, J.; Makaroff, C.A. Arabidopsis thaliana glyoxalase 2-1 is required during abiotic stress but is not essential under normal plant growth. PLoS ONE 2014, 9, e95971. [CrossRef] [PubMed]

103. Bhomkar, P.; Upadhyay, C.P.; Saxena, M.; Muthusamy, A.; Prakash, N.S.; Pooggin, M.; Hohn, T.; Sarin, B. Salt stress alleviation in transgenic Vigna mungo L. Hepper (blackgram) by overexpression of the glyoxalase I gene using a novel Cestrum yellow leaf curling virus (CmYLCV) promoter. Mol. Breed. 2008, 22, 169-181. [CrossRef]

104. Tuomainen, M.; Ahonen, V.; Kärenlampi, S.O.; Schat, H.; Paasela, T.; Svanys, A.; Tuohimetsä, S.; Peraniemi, S.; Tervahauta, A. Characterization of the glyoxalase 1 gene TcGLX1 in the metal hyperaccumulator plant Thlaspi caerulescens. Planta 2011, 233, 1173-1184. [CrossRef] [PubMed]

105. Lin, F.; Xu, J.; Shi, J.; Li, H.; Li, B. Molecular cloning and characterization of a novel glyoxalase I gene TaGLY I in wheat (Triticum aestivum L.). Mol. Biol. Rep. 2010, 37, 729-735. [CrossRef] [PubMed]

106. Alvarez-Gerding, X.; Cortés-Bullemore, R.; Medina, C.; Romero-Romero, J.L.; Inostroza-Blancheteau, C.; Aquea, F.; Arce-Johnson, P. Improved salinity tolerance in carrizo citrange rootstock through overexpression of glyoxalase system genes. BioMed Res. Int. 2015. [CrossRef] [PubMed]

107. Wu, C.; Ma, C.; Pan, Y.; Gong, S.; Zhao, C.; Chen, S.; Li, H. Sugar beet M14 glyoxalase I gene can enhance plant tolerance to abiotic stresses. J. Plant Res. 2013, 126, 415-425. [CrossRef] [PubMed]

108. Saxena, M.; Bisht, R.; Roy, S.D.; Sopory, S.K.; Bhalla-Sarin, N. Cloning and characterization of a mitochondrial glyoxalase II from Brassica juncea that is upregulated by $\mathrm{NaCl}, \mathrm{Zn}$, and ABA. Biochem. Biophys. Res. Commun. 2005, 336, 813-819. 
109. Mustafiz, A.; Singh, A.K.; Pareek, A.; Sopory, S.K.; Singla-Pareek, S.L. Genome-wide analysis of rice and Arabidopsis identifies two glyoxalase genes that are highly expressed in abiotic stresses. Funct. Integr. Genom. 2011, 11, 293-305. [CrossRef] [PubMed]

110. Mustafiz, A.; Ghosh, A.; Tripathi, A.K.; Kaur, C.; Ganguly, A.K.; Bhavesh, N.S.; Tripathi, J.K.; Pareek, A.; Sopory, S.K.; Singla-Pareek, S.L. A unique $\mathrm{Ni}^{2+}$-dependent and methylglyoxal-inducible rice glyoxalase I possesses a single active site and functions in abiotic stress response. Plant J. 2014, 78, 951-963. [CrossRef] [PubMed]

111. Chakravarty, T.N.; Sopory, S.K. Light stimulated cell proliferation and glyoxalase-I activity in callus cultures of Amaranthus paniculatus. In Progress in Plant Cellular and Molecular Biology; Nijkamp, H.J.J., van der Plas, L.H.W., Aartrijk, V.J., Eds.; Kluwer Academic: Dordrecht, The Netherland, 1990; pp. 379-384.

112. Chakravarty, T.N.; Sopory, S.K. Blue light stimulation of cell proliferation and glyoxalase I activity in callus cultures of Amaranthus paniculatus. Plant Sci. 1998, 132, 63-69. [CrossRef]

(C) 2017 by the authors; licensee MDPI, Basel, Switzerland. This article is an open access article distributed under the terms and conditions of the Creative Commons Attribution (CC BY) license (http:/ / creativecommons.org/licenses/by/4.0/). 